\title{
Democratizing University Foodscapes? Student Food Cooperatives and the Neoliberal University
}

Amanda Marple

Follow this and additional works at: https://researchrepository.wvu.edu/etd

\section{Recommended Citation}

Marple, Amanda, "Democratizing University Foodscapes? Student Food Cooperatives and the Neoliberal University" (2018). Graduate Theses, Dissertations, and Problem Reports. 6164.

https://researchrepository.wvu.edu/etd/6164

This Thesis is protected by copyright and/or related rights. It has been brought to you by the The Research Repository @ WVU with permission from the rights-holder(s). You are free to use this Thesis in any way that is permitted by the copyright and related rights legislation that applies to your use. For other uses you must obtain permission from the rights-holder(s) directly, unless additional rights are indicated by a Creative Commons license in the record and/ or on the work itself. This Thesis has been accepted for inclusion in WVU Graduate Theses, Dissertations, and Problem Reports collection by an authorized administrator of The Research Repository @ WVU. For more information, please contact researchrepository@mail.wvu.edu. 


\title{
Democratizing University Foodscapes? \\ Student Food Cooperatives and the Neoliberal University
}

\author{
Amanda Marple \\ Thesis Submitted to the Eberly College of Arts and Sciences at \\ West Virginia University \\ in partial fulfilment of the requirements for the degree of \\ Master of Arts in the \\ Department of Geography and Geology \\ Bradley Wilson, PhD., Chair \\ Cynthia Gorman, PhD. \\ Daniel Renfrew, PhD.
}

Department of Geology and Geography

Morgantown, West Virginia 2018

Key Words: Student Food Cooperatives, Alternative Economies, Neoliberal University, Student Activism, Food Sovereignty

Copyright 2018 Amanda Marple 


\section{Democratizing University Foodscapes? Student Food Cooperatives and the Neoliberal University}

According to a report published in 2015, the National Center for Education estimated that over 20 million students were forecasted to enroll in higher education in the 2016-17 school year, situating American universities as major institutional food retailers. Over the past two decades, corporate food providers have increasingly sought long-term public and private university contracts as a means to expand their reach into lucrative campus food landscapes (foodscapes), replacing in-house services with cheaper, more "efficient, and "productive" dining strategies. Companies such as Sodexo, Aramark, and Bon Appetit control the foodscapes of many university campuses across the United States, creating food environments dominated by corporate interests.

However, at the same time these corporate food service providers have colonized university food terrains, a growing movement of consumers concerned with ethical food sourcing have driven students across the United States to seek alternatives to dominant food sourcing strategies on their campuses. In a context of increased corporate control over their university foodscapes, student across the US have launched campaigns aiming to develop and establish student food cooperatives (SFCs), organizations seeking to assert the availability of sustainable, ethical, and healthy food options on campus in addition to pushing for more student decision-making power within their university food environments (Marsden, 2000).

It is within this context that my thesis aims to explore if and how student food cooperatives are creating new spaces for food sovereignty and if they are democratizing the control over their university food systems through campus based food initiatives. 


\section{Table of Contents}

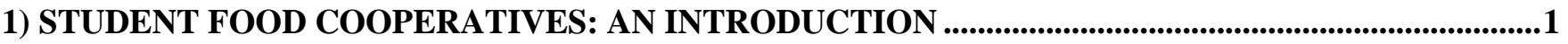

2) THE COOPERATIVE FOOD EMPOWERMENT DIRECTIVE (COFED) ...............................................3

3) FOOD SOVEREIGNTY, FOOD JUSTICE, AND THE FIGHT FOR AUTONOMOUS FOOD

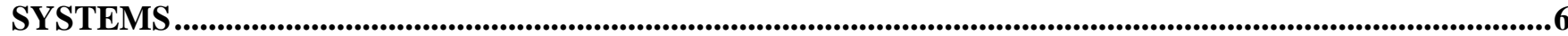

4) DIVERSE AND ALTERNATIVE ECONOMIES: STUDENT FOOD COOPERATIVES AN

ECONOMIC CONTEXT .8

5) BACKGROUND ON CAMPUS BASED ACTIVISM: THE COOPERATIVE FOOD

EMPOWERMENT

DIRECTIVE, UNITED STUDENTS AGAINST SWEATSHOPS, AND UNITED STUDENTS FOR FAIR TRADE.

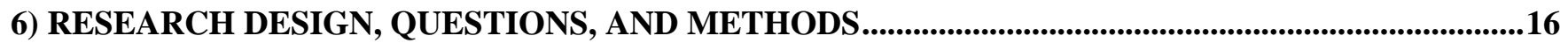

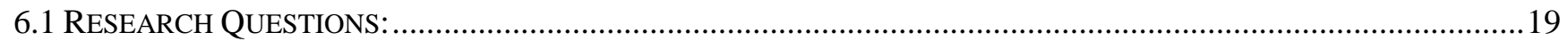

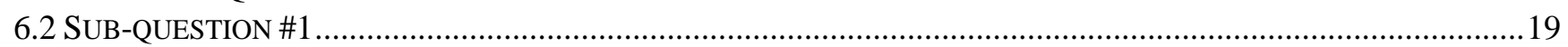

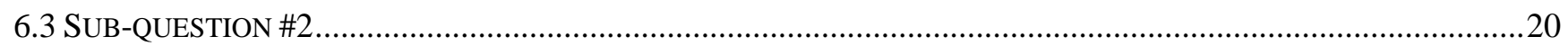

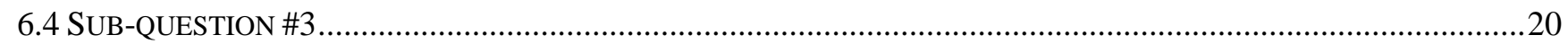

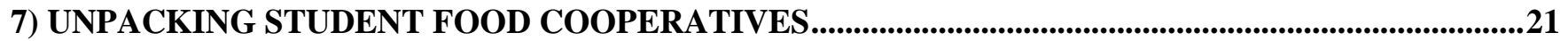

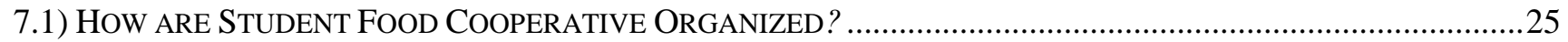

7.2) BARRIERS AND CHALLENGES FACING STUDENT FOOD COOPERATIVES WITHIN THE UNIVERSITY CONTEXT

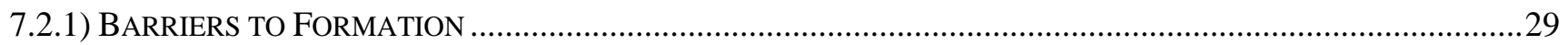

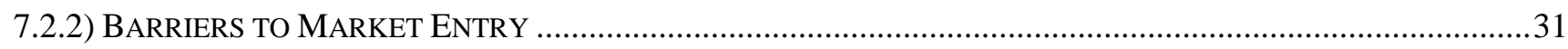

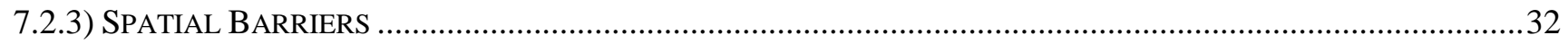

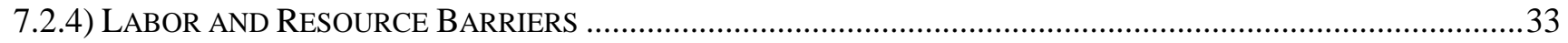

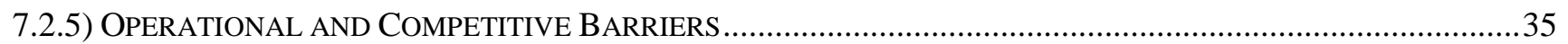

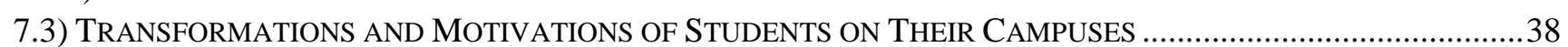

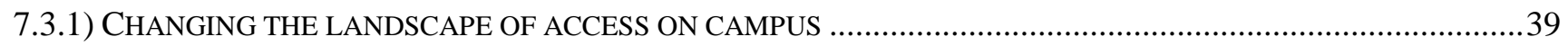

7.3.2) INDIVIDUAL TRANSFORMATION BY ENGAGING WITH COOPERATIVE SPACES .....................................40

7.3.3) CREATING A SENSE OF COMMUNITY AND SOLIDARITY WITH ONE ANOTHER .........................................42

8) HOW IS COFED NAVIGATING STUDENT COOPERATIVE BARRIERS? .....................................42

9) FOOD COOPERATIVES FOR WHOM? EXCLUSION WITHIN "INCLUSIONARY" SPACES.........48

10) BEYOND FOOD COOPERATIVES TO DIVERSE COLLECTIVITIES .............................................50

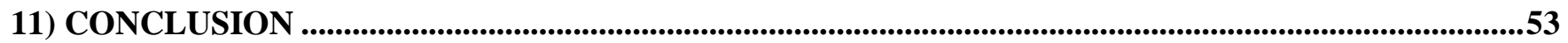

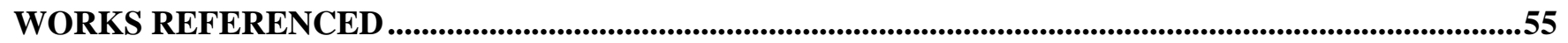

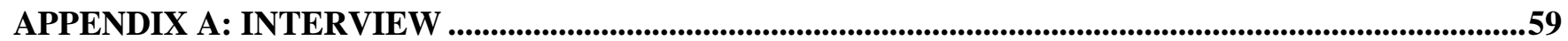

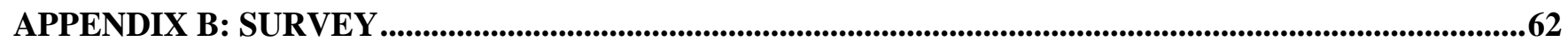




\section{1) Student Food Cooperatives: An Introduction}

With over 20 million students enrolled in higher education across the United States, universities are major food retail hubs (National Center for Education Statistics, 2017). Over the past two decades, corporate food service providers (FSPs) have increasingly sought long-term public and private university contracts as a means of expanding their reach into the lucrative campus food landscapes (foodscapes), replacing in-house services with cheaper, "more efficient and productive" dining strategies (Giroux, 2002). Companies such as Sodexo, Aramark, and Bon Appetit control the foodscapes of many university campuses across the United States, creating food environments dominated by corporate interests. However, at the same time FSPs have colonized university food terrains, a growing movement of consumers concerned with ethical food sourcing have also driven students to seek alternatives to dominant food sourcing strategies on their campuses. In a context of increased corporate control over university dining and a yearning for more sustainable, equitable, and just food systems, university students across North America have launched campaigns to source organic and local foods, promote inclusive vegetarian, vegan, gluten-free diets, advance campus-based food production, and support ethical purchasing of foods.

At the forefront of many of these campaigns are student-led food cooperatives (SFCs), organizations seeking to transform corporately controlled campus foodscapes, and promote democratic student control through cooperative business models. These SFCs assert the availability of healthy, sustainable, and ethical food options on campuses in addition to pushing for more student decision making power within their university food environments (Marsden, 2000). 
However, establishing and maintaining cooperative businesses and stores places students in conflict with other campus actors (university administrations and corporate dining services) vying for control over university space and food operations. In other words, the university foodscape can be seen as a site of struggle between competing corporate and cooperative food strategies and campus administration. In such spaces of struggle, student food cooperatives face formidable tasks of negotiating an institutional context where corporate dining services are typically dominant; affecting their abilities to establish and expand models of cooperative student control over campus food outlets. The creation of food cooperatives on campus exemplifies the latent power dynamics inherent in current university environments; students are rarely granted the ability to produce and control their own food on campus, and are typically left out of decision making processes that affect their food consumption within university spaces.

To fully understand the environment and motivations of student food cooperatives in the United States, I conducted a 2-year study with co-ops affiliated with the Cooperative Food Empowerment Directive (CoFED), which is currently the only national organization working to support, promote, and connect SFCs in the United States and Canada.

In this thesis, I explain the development of student food cooperatives as well as student motivations to form cooperatives. To give context to student food cooperatives within relevant conversations, of I have placed them within contemporary discussions of student activism, food sovereignty, and the creation of diverse economies. Throughout this paper, I show how SFCs navigate institutional and corporate food environments on campus, uncover challenges SFCs may face in forming cooperative businesses, and highlight the different motivations and meanings of food co-ops that students bring to their organizations. By using the historical context of USAS and USFT to couch my study of SFC in the United States today, I argue a shift has happened in 
the way some students on college campuses enact their activism; creating a movement in which the students themselves control their own means of food production, consumption, and/or distribution in the form of student food cooperatives and collectives. In this way, students across the country are forming and performing diverse economies through alternative food stores. This research illustrates that through collaborative actions, student food cooperatives create a space where students can attempt to democratize their foodscapes on campus; stemming from a need to access particular foods (vegan, vegetarian, or gluten free) and as a way to politicize and resist food policies on campus (Estabrook, 2011). Not only do these campus food cooperatives provide a space for students to think, rethink, and enact their food politics and activism, these spaces also create new environments for self-transformation; allowing students to become part of these cooperative food communities and take on responsibilities they may have not encountered otherwise. Students on college campuses are reworking what it means to participate in movements on campus by creating these cooperative and collective food spaces and opportunities for students, and non-students, to explore alternative economic models and futures.

\section{2) The Cooperative Food Empowerment Directive (CoFED)}

My work focuses on the 26 current SFCs affiliated with the Cooperative Food Empowerment Directive, a nonprofit organization providing tools and trainings to student communities that wish to establish healthy and more sustainable food options on their campuses and creating a dynamic network of student food co-ops to promote thriving, equitable, and resilient local economies. Finding its roots in the 2009 Berkeley student protests against the inclusion of a Panda Express on the UC Berkeley campus, CoFED formed when students interested in building a student food cooperative in place of the Panda Express began researching how to develop their own cooperative business. While researching student-led food cooperatives, 
they realized there were other operational SFCs across the country that had no network in place to easily communicate with one another. Hoping to create a dynamic network of cross-country SFCs, connect students to on-campus and national resources for cooperative development, and foster a community of learning surrounding student food sovereignty and democratic working environments, CoFED officially launched in 2010 with the goal to develop at least five student cooperatives in five years and connect existing cooperatives to one another (Isaacs, 2011).

Since the organization's inception in 2010, CoFED has worked with over 75 student teams and over 1,000 individuals to develop campus food cooperatives from the ground up with university administrations and students, as well as strengthening existing SFCs on campuses across the United States and Canadian universities. CoFED actively researches student food cooperatives in the United States and conducts outreach with university administration, faculty, and student organizations already established on campuses such as The Real Food Challenge, Sierra Club, Food Recovery Network and campus Community Gardens. Currently, CoFED is the only national organization working with student food cooperatives in the country, having the only catalog of SFCs available (Isaaccs, 2016).

In the last seven years, CoFED has gone from a California based organization aiming to connect cooperatives mainly on the West Coast to a nationally recognized student cooperative organizing entity. After they branched out from their West Coast organizing, CoFED structured themselves with regionally based organizers located mostly on the coastal United States, mirroring The Real Food Challenge's organizing strategy. This reflects in the geographical distribution of CoFED's student cooperatives network; there are no cooperative organizations associated with CoFED in the central part of the country, something the organization has identified as an area of needed improvement (Isaacs, 2016). They have since moved on from this 
regional organizing strategy, but still maintain the same geographical distribution of cooperatives.

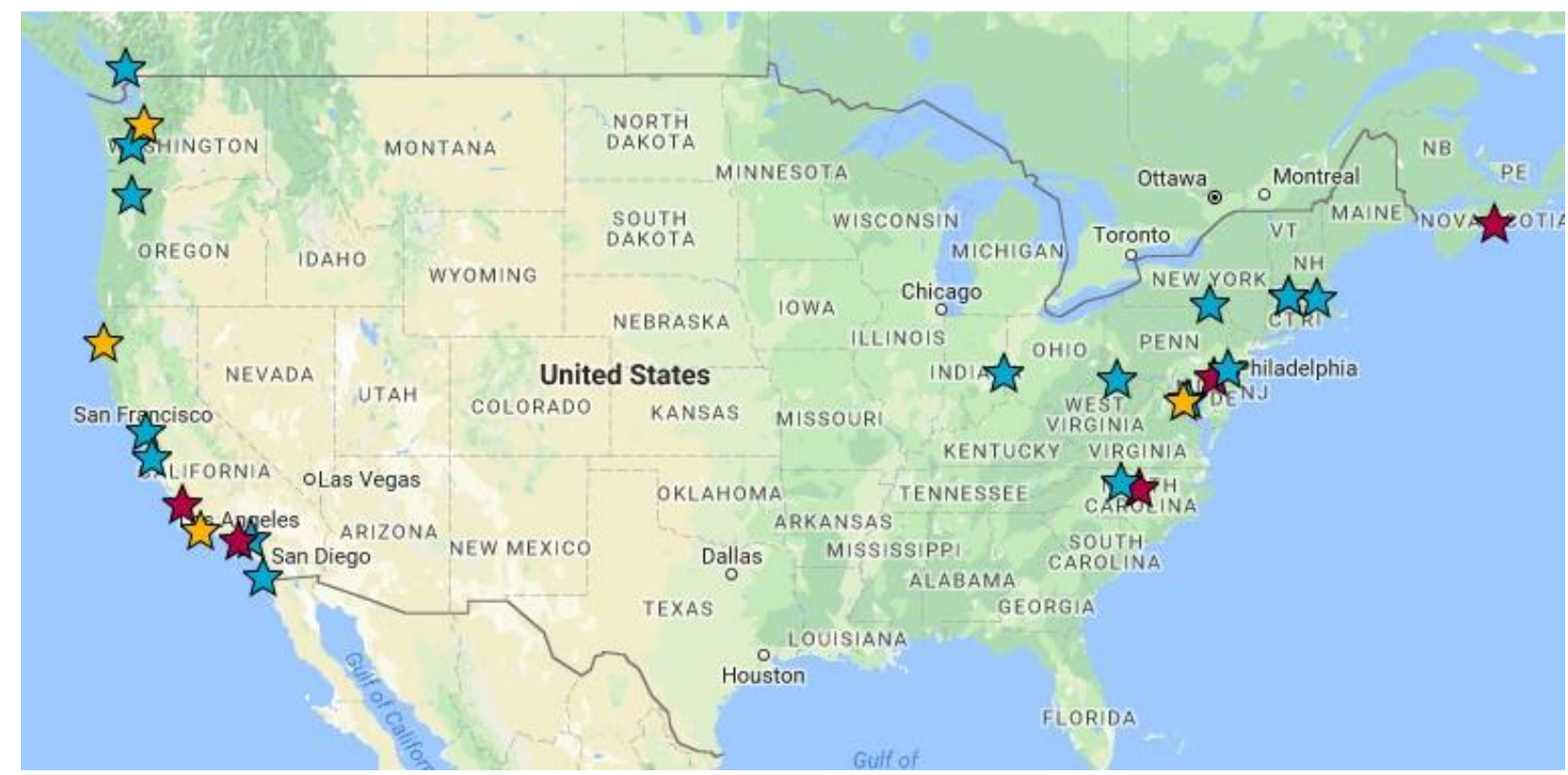

Figure 1 CoFED National Map www.cofed.org

In conjunction with their nation-wide organizing, over the last 5 years, CoFED has shifted away from part-time regional organizers by consolidating their staffing to three full time positions, and focusing on fully developing their justice based educational programming. Over the last two years of research engagement, I have also witnessed CoFED's changing leadership with three Executive Directors in the last two years, and two long-time staff members stepping down. This change in leadership has affected the organization's focus. With the change in staff, organizing focus, and shifting educational programing, CoFED's overall work is changing to suit the needs of the cooperative movement they aim to support and develop, bucking their original approach to enhance their impact with young people across the country more broadly. CoFED has also become more selective in their Summer Institute application process, becoming more 
aware of the social, racial, and gender identities of their cohorts. This highlights the increased attention being paid to identity politics within their cooperative development strategies.

\section{3) Food Sovereignty, Food Justice, and the Fight for Autonomous Food Systems}

Cooperatives organize for a variety of reasons, but the student businesses included in this study are strictly focused on food's production, distribution, and consumption. Since student coops are formed to control some aspects of the food being served and consumed on their campuses, it is necessary to ground them within the literature of food sovereignty and justice. The food sovereignty literature adds both theoretical and applied knowledge which links student co-ops to larger food movements across the globe, with food activists in the US taking cues from food sovereignty movements mostly occurring in the rural, small scale, and peasant agricultural settings in much of the global south.

The food sovereignty movement "prioritizes production for local and domestic markets, demands fair prices for food producers, and emphasizes community control over productive resources such as land, water and seeds" (Alkon, Mares 2012), all facets of which are lost when global food regimes take control of local peasant markets. Taking cues from these peasant movements in the global south, US food activists advocate against large corporate food regimes and fight for transparency, control, and access to healthy and appropriate food options. As mentioned above, food sovereignty is a "counter-hegemonic [counter capitalist] discourse that questions the organization of the current food system and calls for its transformation" (Hopma and Woods 2014).

Stemming from principles of food sovereignty and related to the fight for access of healthy and appropriate foods, food justice is understood as the "emphasis on the role of the built environment and longstanding patterns of racial and class-based inequalities in producing 
inadequate access to healthy food" (Alkon and Mares 2012). Not unlike food sovereignty

activists, food justice advocates are concerned with access, but their main concerns deal with the race and class based inequalities that are a part of access to high quality foods. Food justice advocates have tended to ignore the role large food regimes play in marginalizing certain populations, suggesting that market access will improve overall well-being of those who are without. Going further, food sovereignty activists advocate for a complete transformation of the food system in recognizing the state and local communities as actors that could alleviate corporate control over food production. While both arguments are valid, food justice activists tend to leave out a large part of the picture when advocating changes in the current food system. Holt-Gimenez separates food justice and food sovereignty activists into two the strains of progressives and radicals. "While progressives focus more on localizing production and improve access to good, healthy food, radicals direct their energy at changing regime structures and creating politically enabling conditions for more equitable and sustainable food systems.... Together, folks in this global food movement seek to open up food systems to serve people of color, smallholders, and low-income communities while striving for sustainable and healthy environments. Radicals and progressives are the arms and legs of the same [larger] food movement" (Holt-Gimenez, 2010).

The distinction between these two types of food movements is important to highlight when discussing student food cooperatives in the United States and the organizing strategies of CoFED. Whether or not these student cooperatives frame their work as aligning with food justice or food sovereignty movements distinguishes their roles within broader food movements. This calls into question the missions of student food cooperatives in relation to their respective campuses. Are they truly advocating for real changes in their food systems on campus (sourcing, 
wealth inequality, humane foods, etc.), or are they acting as food justice activists in attempting to address the issue of food access without questioning the larger economic and social systems that create food inequality and inaccessibility?

\section{4) Diverse and Alternative Economies: Student Food Cooperatives an Economic Context}

Cooperatives are an economic alternative to capitalist enterprises, which have tendencies to exclude the local, community, and social needs of producers, workers, and consumers. JK Gibson-Graham (1996) argue against capitalism as an autonomous and inherent hegemonic economy. Rather, they argue that economies are a conglomerate of systems that exist simultaneously and that can make other worlds possible through cooperation, to oppose corporate dominance and hegemony. Students engaged with food cooperatives are both actively and passively creating alternative economic forms on campus. Student food cooperatives can be seen as just one example on campuses of how different economies exist within the same spaces.

Therefore, to begin writing on student food cooperatives, it is important to set my work within the broader discussions surrounding alternative economies. With the publication of J.K. Gibson-Graham's The End of Capitalism (As We Knew It): A Feminist Critique of Political Economy in 1996, a new concept of economies was revealed. This work introduced the idea of economic alternatives by deconstructing capitalist social and economic systems, and by giving visibility to economies that have effectively been deemed "invisible" in its shadow. After The End of Capitalism was published, the topic of diverse economies within economic geography gained momentum. It opened the door for the development of the diverse economies research program (Gibson-Graham, 2008) which has enabled scholars, in various disciplines including geography, to begin "reading for difference in the economic landscape - investigating failures of formal institutions and 'openings' in capitalism" (Fickey, 2011). Gibson-Graham argue about the 
importance of academic activism and the need to "place new responsibility on the shoulders of scholars... and their power to bring about new worlds into being" (Gibson-Graham, 2008).

Throughout the literature on diverse economies, a repeated emphasis is on the economy as a heterogeneity of economic relations. Depicting this heterogeneity, J.K. Gibson-Graham provide a table of economic systems that help to visualize diverse economies from three different columns detailed below as Transactions, Labour, and Enterprise. This table does an excellent job laying out the various ways in which diverse economies can operate outside of a conventional capitalist economic system. Placing student food cooperatives into the diverse economies table, one can identify several points in which they relate. First, following along the chart from left to right starting with Transactions, SFCs enter into the Market by offering ethical "fair trade" market options, trade and buy within local food systems, and are organized to engage with co-op exchanges. Moving on to the Labor section of the table, SFCs engage with both alternative and unpaid wage labor in the form of cooperative and volunteer labors. The final column in the table shows alternative Enterprise models, highlighting capitalist alternatives and non-capitalist business models. Student food cooperatives fit into this column by existing as, in some cases, nonprofits and socially responsible firms. Moving down the column, some SFCs are also organized to be communal (within a student community) or collectively run and organized businesses, structuring themselves within a Non-capitalist framework.

This table shows the various ways in which businesses and organizations can navigate the landscape of economic difference, highlighting the possibilities to engage with economies outside of a strictly capitalist framework. Placing student food cooperatives within this table also illustrates the ways in which their businesses deviate from "business as usual" practices and their inherently anti-capitalist models. 


\begin{tabular}{|c|c|c|}
\hline Transactions & Labour & Enterprise \\
\hline Market & Wage & Capitalist \\
\hline $\begin{array}{l}\text { Alternative market } \\
\text { - Sale of public } \\
\text { goods } \\
\text { - } \\
\text { Ethical 'fair-trade' } \\
\text { markets } \\
\text { - Local trading } \\
\text { - } \text { Alstems } \\
\text { Alternative } \\
\text { - } \text { Currencies } \\
\text { - } \text { markerground } \\
\text { - Co-op exchange } \\
\text { - } \text { Barter } \\
\text { Informal market }\end{array}$ & 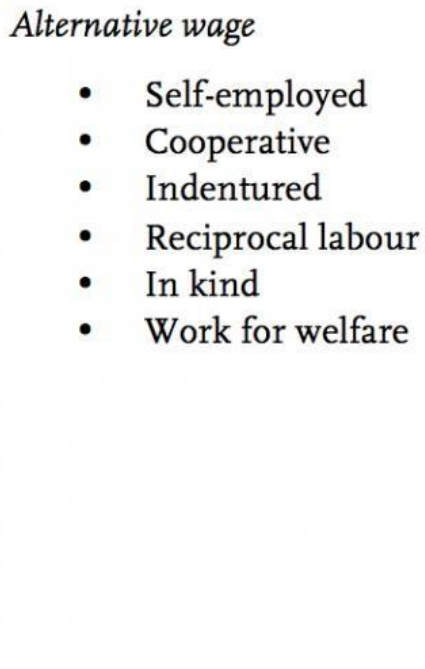 & $\begin{array}{l}\text { Alternative capitalist } \\
\begin{aligned} \text { - } & \text { State enterprise } \\
\text { - } & \text { Green capitalist } \\
& \text { Socially } \\
\text { - } & \text { responsible firm } \\
& \text { Non-profit }\end{aligned}\end{array}$ \\
\hline $\begin{array}{ll}\text { Non-market } \\
\text { - } \\
\text { - } & \text { Gousehold flows } \\
\text { - } & \text { Indigingng } \\
& \text { exchange } \\
\text { - } & \text { State allocations } \\
\text { - } & \text { State } \\
\text { - } & \text { appropriations } \\
\text { - } & \text { Hunting, fishing, } \\
& \text { gathering } \\
\text { - } & \text { Theft, poaching }\end{array}$ & $\begin{aligned} \text { Unpaid } & \\
\text { - } & \text { Housework } \\
\text { - } & \text { Family care } \\
\text { - } & \text { Neighbourhood } \\
& \text { work } \\
\text { - } & \text { Volunteer } \\
\text { - } & \text { Self-provisioning } \\
& \text { labour }\end{aligned}$ & $\begin{array}{l}\text { Non-capitalist } \\
\begin{array}{l}\text { - } \\
\text { - } \\
\text { Indepenmunal }\end{array}\end{array}$ \\
\hline
\end{tabular}

Figure 2 JK Gibson-Graham (2006) A Diverse Economy Table

Although the reading of diverse economies provides a groundwork for beginning to see the world outside of an exploitative capitalcentric lense, possibilities of oppression can still be found within these "progressive" and "alternative" spaces. No economic space is inherently liberatory or radical, meaning that a critical look into economic "alternatives" is essential when exploring the possibilities (Wright, 2010). All economies are structured by power dynamics, but the ability to explore and transform these dynamics and economic formations are what make the 
notion of diverse economies different. The literature on diverse economies is essential in understanding how cooperatively run businesses are viewed within the economic landscape.

\section{5) Background on Campus Based Activism: The Cooperative Food Empowerment Directive, United Students Against Sweatshops, and United Students for Fair Trade}

In order to couch my study of student food cooperatives within a broader understanding of student engagement and university politics, it is also necessary to focus on past student activism and resistances. Student initiatives on college campuses across the United States have historically built powerful movements pressuring universities and large corporations to address issues related to labor and human rights, ethical consumption and purchasing, and environmental degradation. Students, holding unique societal positions in regard to their education, free-time, and responsibilities, have showcased amazing efforts to challenge social and economic status quo in the United States, and in some instances, have succeeded in shifting its equilibrium to accommodate certain concerns which do not wholly threaten dominant hegemony (Hebdige, 1979).

CoFED is embedded in a history of student activism related to two movements that exemplify the creative strategies and power students possess to make changes on their campuses and even in corporate business strategies: United Students Against Sweatshops (USAS) and United Student for Fair Trade (USFT). These initiatives created important paths for today's students concerned with the ills of economic and social policies, food systems, and access to healthy and appropriate foods on campus to potentially establish new spaces for democratic control over foods consumed on campus in the form of student food cooperatives.

Since 1997, USAS has involved over 200 college campuses in their campaign to push universities to adopt more stringent apparel manufacturing standards. The more prominent 
involvement of college students in the movement has "transformed university campuses into key sites of struggle, support and engagement on the anti-sweatshop front" (Cravey 2004). By using their positions as students at top-ranking public and private institutions, USAS members used this power to highlight issues of worker struggles and rights, both abroad and on campus, establishing a worker-student solidarity network. By incorporating labor situation from both abroad and at home into their narrative, USAS chapters have bridged the gap between local and global struggles, addressed the "white man's burden" and "white savior" mentality many students have attached to the movement, and created a transnational worker-student solidarity based in struggles across the globe (Silvey 2002). This is done through launching living wage campaigns addressing low wages for university staff, particularly food workers and janitors, as well as clothing factor workers abroad.

This shift to additionally focus on low-wage workers in the United States was driven by the involvement of student campaigns on campus. This highlights an important change students brought to the US based anti-sweatshop movement, creating grounds for a more realized transnational solidarity. The local and global focus of USAS campaigns also aims to interlink local decision-makers (such as university administrators, corporate contractors, and athletic departments) with policies that have global implications such as labor conditions in overseas factories, transnational corporation production chains, marketing, and consumption (Silvey 2004). Targeting the local to transform global practices shows the ability of grassroots organizations, such as USAS college affiliates, to change and re-shape international policy. Forming six years after USAS, United Students for Fair Trade (USFT) came onto the student movement scene in 2003 with pushes to incorporate fairly traded commodities into the mainstream consumer market (Wilson \& Curnow 2013). USFT student activists promoted and 
supported the Fair Trade Certified label, launched local, campus based and national campaigns, educated consumers and peers, and used "relentless, persuasive, and at times coercive forces" (Wilson \& Curnow 2013) targeting universities and corporations to increase awareness and create avenues for increased market availability. These USFT activists were a completely volunteer labor force who marketed FTC products locally and nationally, carried out sales deals on campuses, and commercialized the Fair-Trade label for free.

However, eight years after its inception, USFT released a statement withdrawing support from the major fair-trade certifier, FairTradeUSA, to encourage a boycott of FTC products, a tactic never endorsed previously. This withdrawal from FairTradeUSA stemmed from the NGO's decision to resign from the International Fair Labelling Organization (FLO), which internationally regulated fair-trade products and excluded some products from certification. The brand USFT had worked so hard to support and promote had opted out of international regulation standards to incorporate more products and corporate interests into the FTC label. The affective labor USFT activists had seen as work-in-solidarity with farmers and producers had been coopted by FairTradeUSA to endorse ethical branding campaigns by corporations looking for new markets and consumers. Frustrated and angry by this realization, USFT activists who had seen their labor benefiting farmers and producers, not corporations, spearheaded a radical campaign to boycott the very product and industry they had once worked so hard to promote. However, not all USFT activists were in support of the withdrawal from FairTradeUSA, causing the organization to splinter. Some activists continued to support FTC, stating that it was better than no ethical standards at all. Others either dropped out of Fair Trade activism all together, feeling burned by the experience and hard work they had put in for years, or began to boycott FTC and look for and 
create alternatives to promote a truer version of fair trade, one they believed they were developing in the first place.

Without student activists and their free marketing, sales, and education strategies, the Fair-Trade movement in the US may not have caught on at such a high rate within the wider public. The student labor and passion for what they saw as an alternative to conventional "business as usual" practices lead to FTC earning widespread consumer "seal of approval". However, their activism and withdrawal from FTC and FairTradeUSA draws attention to issues stemming from ethical consumption and marketing, highlighting the susceptibility to "cheap marketing ploys" and corporate co-optation of movements pushing for social and economic change.

After delving into the literature of student organizing, it is clear that CoFED is historically related to these student initiatives, building upon their work, and addressing the limits both USFT and USAS without explicitly linking themselves to these organizations and their experiences. By supporting organizations to create democratic student owned businesses on campus, CoFED responds to USAS's campaigns to push companies and universities into the Workers' Rights Consortium (WRC) and USFT's lack of control over fair trade certification. CoFED moves the locus of power to student decision making and ownership over retail locations on campus, granting them control over what they do and how they do it.

These university power dynamics and response of SFCs could be seen as creating a discourse of food sovereignty on campus, questioning who has the power to control what is available and consumed on campus; students or corporate dining services? The food sovereignty movement, "prioritizes production for local and domestic markets, demands fair prices for food producers, and emphasizes community control over productive resources such as land, water and 
seeds" (Alkon and Mares 2012). In this movement against large corporate food regimes, activists fight for transparency, control, and access over healthy food options in the US. As the movement rises the in US, a discussion has been sparked debating whether a variety of food movements are actually focused on principles of the food sovereignty, or are more related to exclusive movements like "healthism" and local "foodism" (Guthman, 2008). Whether or not SFCs are creating spaces for alternative food movements to thrive or even enacting core principles of food sovereignty are topics that must be explored in order to truly understand where they fit into the spectrum of food movements and diverse economies.

The intersection of student activism, the creation of alternative economies, and food sovereignty provides groundwork to begin building my own study of student food cooperatives. Students, such as those in USAS and USFT, have incredible potential to begin a transformation of the status quo and change its equilibrium. By attempting to create alternative economic models on campus, SFCs allow students the opportunity to explore diverse business practices that diverge from "business as usual" discourses typically taught in American universities. By providing a space for students to explore different economic models, SFCs can be seen as a mechanism in which students can perform democracy and gain some modicum of control over their unsatisfactory foodscapes, which are typically not student-centric or inclusive. Because these organizations combine the creation of democratic and inclusive business practices with a discourse related to the control over food consumption and availability, SFCs have the potential to be incredibly radical spaces for learning, democracy, and the implementation of food sovereignty on campus.

However, the potential for co-optation looms, demonstrated by the disbandment of USFT in the late-2000s. The threat of SFC co-optation, because of their relationship with universities 
and corporate dining services, remains problematic in regard to the degree to which these organizations can actually enact radical food democracy on campus. This aspect of SFCs highlights the university as a space of struggle between actors vying for control of campus foodscapes and also lends to considerations surrounding whether students are pushing for radical food systems changes or are just interested in access to more exclusive and "healthy" food options on campus. By connecting the frameworks of alternative economies and food sovereignty, I dissect SFCs to assess the degree to which students are actually pushing for either. Understanding how students see their actions in these SFCs sheds light on what issues they are actually interested in addressing on campus. However, as I have found throughout my research, there are not just externally oriented power dynamics at play in these student food cooperatives. Internal dynamics also create exclusionary practices within the cooperatives themselves, creating unintentional hierarchies of power.

\section{6) Research Design, Questions, and Methods}

My research methodology is shaped by post-structuralist feminist thought; aiming to understand the creation of student food cooperatives in response to anti-capitalist economic and social concerns on university campuses. This methodology informs the way I uncover and understand the varying power dynamics at play within university spaces, and acknowledge that there are always multiple power differentials at play (Allen 2003). A post structural feminist methodology also provides powerful tools to analyze identity beneath student motivations which inform what types of issues are seen as important to particular students and cooperative organizations based upon their standpoints, social realities, and situated knowledges (McCann and Kim 2013). Everyday life experiences reflecting race, class, and gender inform the ways in which students participate and engage with the physical space and idea of campus SFCs. It is 
necessary to understand the contexts framing the lives of student cooperators is in order to define their relationship to SFCs, food activism, and the creation of economic and social alternatives (Naples, 1998). By taking this posture, my research explores how power dynamics at work in university spaces shape the social and economic subjectivities of students, how positionality affects the motivations of students performing and engaging with cooperative economic alternatives, and how university students participate in economic alternatives addressing food governance, access, and justice on their campuses.

My work is also shaped by my position as a student cooperator, involved with food based social initiatives at West Virginia University. My experiences working on projects related to alternative / diverse economies and food justice in the state of West Virginia have not only shaped the intellectual posture to study university student food cooperatives, but also the questions I aim to answer with this research. Coming to this research versed in diverse economies, food sovereignty, and social action frameworks shaped the way I approached the study. In trying to better understand the significance behind the collective performative actions of SFCs on university spaces, I explored the internal motivations of individuals presumably working, toward economic, social, and food systems change. Knowing why and how students are motivated to engage with cooperative food enterprises informs the significance and relevance of SFCs within broader alternative economies and food sovereignty movements.

With over five years of experience working closely with students in cooperative business environments, I often performed the position of "insider" with my informants throughout the research. My experience organizing a student cooperative has enabled me to delve deeply into university culture, cooperative organizational dynamics, and individual student motivations. In addition, understanding how university food services operate provided a point of comparison 
with other student food cooperatives, drawing upon my own knowledge of cooperative spaces, university politics, and student engagement.

To achieve my research goals, I used qualitatively-based mixed methods; a survey of the 26 cooperatives in the CoFED network, semi-structured interviews with 14 key informants from student cooperatives, and four separate instances of ethnographic participant observations in order to fully understand the conditions in which student cooperatives are developing and the motivations pushing students to work in cooperative business structures. This study has also leveraged my experience as a student cooperator working closely with FIRSTHAND Co-op at West Virginia University, affording me an “insider" position during the research process. My positionality and years of experience allow for a more in-depth point of comparison between other student cooperatives by drawing upon my own knowledge of cooperative spaces, language of the cooperative movement, university politics, and student engagement.

My mixed-method approach afforded me three different avenues to assess the intricacies of if and how SFC are creating new spaces for the democratic control of food on campus. By employing a survey of the entire CoFED network I gained a broader understanding of the environments in which SFCs are developing and functioning, and how students are cooperatively organizing themselves. These surveys were meant to delineate a basic understanding of the types of organizations currently affiliated with CoFED. Semi-structured interviews were held with key informants from five student food cooperatives at universities in the United States. The semistructured interviews allowed for more personal and in-depth conversations surrounding student motivations, specifics pertaining to their SFC, and university relationships on campus. Here, I was able to leverage my "insider" position as a student cooperator to move beyond any public relations walls that an outsider may have encountered. Lastly, I incorporated ethnographic 
participant observation into my research during CoFED's Summer Institute in July of 2015. I found this deepened connections and conversations with students who were interviewed, leading to the disclosure of information that may have not been given without prior engagement. The use of participant observation also afforded me the opportunity to gauge the extent to which students were educated about cooperativism, food sovereignty, and university-based politics without individual interviews. I used ethnographic participant observation during two CoFED Summer Institutes in 2015 and 2016, as well as two SFC site visits to learn how these co-ops are functioning in practice and how these SFC relate their missions and values to the day-to-day operations.

\subsection{Research Questions:}

How do student food cooperatives create new spaces for food sovereignty and democratize control over university food systems through campus-based initiatives?

\subsection{Sub-question \#1}

What motivations support individual student engagement in an SFC?

In any study aiming to examine social movement phenomena, the question of individual motivation is important when trying to research the movement more broadly. Understanding what draws individuals to a movement and what continuously motivates them to participate is crucial for the survival of and extent to which the movement can create meaningful change. This question also lends to uncovering the multiple identities of students who participate in SFCs; digging into how their social locations affect who engages with the SFC, and how the meaning of democratic spaces, food sovereignty, and activism change depending upon a student's embodied experiences. 


\subsection{Sub-question \#2}

How are students organizing their cooperative businesses on campus?

The organizational structure of an SFC informs what they actually do on campus and how they do it. Exploring the organizational forms (worker-owned, consumer owned, multistakeholder) of SFCs allowed for a broader analysis of cooperative organizational and governance trends on campuses. It also highlights who holds the power to make decisions within the cooperative space; uncovering who is actually controlling what happens in the cooperative, whether or not their cooperative engagement is truly democratic or even pushing for democratic control of food on campus, and if the organization is truly a cooperative enterprise.

\subsection{Sub-question \#3}

How are SFCs currently navigating institutional and corporate foodscapes on campus?

This question aims to understand the ways students are forced to navigate their institutional and corporate foodscapes on campus, highlighting barriers and challenges SFCs face in trying to democratize their food provisions and choices. Corporate dining barriers facing students show just one of the many consequences related to neoliberal policies on university campuses across the United States. Uncovering how students address their perceived lack of control over the food on campus lends to understanding whether or not they are actually creating spaces of economic alternatives, and if they even understand how the neoliberalization of their university affects their ability to demand control of the food served on campus.

\section{Data Collection}

I conducted 14 semi-structured interviews (Appendix A) with student cooperative members from five universities in the United States. A survey (Appendix B) of the 26 current 
CoFED student food cooperatives was conducted yielding responses from 23 students from 11 universities in the United States. In addition to semi-structured interviews and a network survey, I conducted four separate participant observation studies, two during CoFED's 2015 and 2016 Summer Institutes and two at student food cooperatives, one California and one in Pennsylvania.

\section{7) Unpacking Student Food Cooperatives}

On college campuses across the United States student-run food cooperatives and collectives have become a more frequent sight over the last two decades, stemming from second wave cooperative development starting in the 1970s. These student-led food initiatives can be found all over the country; from California to North Carolina, from Georgia to Maine. Student food cooperatives range in size, mission, function, and organizational structuring; there is no one-size fits all approach to the development and success of these organizations, especially taking into account their spatial and institutional contexts of operation.

Campus based student-run food cooperatives are organizations that aim to work cooperatively in order to provide sustainable, ethical, healthy, and affordable foods (prepared, bulk, fresh produce, etc.) to their peers and campus based communities. Ideally, just like any neighborhood food cooperative, SFCs work to meet needs that their community lacks or falls short of fully addressing. Whether that be the need for addressing food insecurity on campus, providing sustainable and ethical food options, access to fresh and healthy produce, or providing food options for students with certain dietary restrictions or needs, student run cooperatives work to address aspects of their campus food landscapes which are mostly not being met. These co-ops also try to address the lack of student decision-making power in regard to their food options on their campuses; recognizing the disconnection between who consumes food on campus and those making the decisions about what foods are served. As one survey participant noted, "We address 
the lack of healthy sustainably sourced food on campus. The lack of student inclusion in decision-making that affects the student life" (CoFED Survey, 2016). The needs that these student food cooperatives address are highly varied, depending on the geography, social, and economic landscape of these cooperatives. These needs may address concerns about their broader campus community as one student pointed out, "We live far away from cheap grocery stores. You have to be on a bus for an hour to get to a decently priced store. We provide cheap food on campus for those who can't drive, don't have cars, or some mobility issues that make hour long bus rides terrible". And as another student reflected, "We want to address student hunger and poverty: not just monetarily poor, but time poor and resource poor. Students live in residence halls with bad or inappropriate food choices". On the other hand, the needs these SFCs meet may reflect self-identified needs from cooperative members themselves, as suggested by another student cooperator stating they work for, "food politics [to have] a presence on campus and educating people on issues around intersectional food politics," (CoFED Survey, 2016). Neither form of need is better than the other, but this highlights the process of who the spaces are actually made for.

In line with how most cooperative businesses function, these student organizations generally operate in a democratic, horizontal manner; meaning no one person has any ultimate power to make final decisions or override any collectively agreed upon actions. Most cooperatives also follow at least one or two of the seven guiding cooperative principles, defined by the International Cooperative Alliance as: 1) voluntary and open membership, 2) democratic member control, 3) member economic participation, 4) autonomy and independence, 5) education, training, and information, 6) cooperatives amongst cooperatives, and 7) concern for the community (ICA, Cooperative Identity, Values and Principles). However, most student 
cooperatives that included in the study have not truly encompassed all seven cooperative principles at once. Since these cooperatives are mostly university based and are usually formed as student organizations, most SFCs are volunteer run. There are, however, a few outliers that are fully autonomous, operating outside of the university. And there are others that have university funding or "work study" positions subsidizing the workloads of some students, "We have a few work study positions... they don't have more power than anyone in the group, but they are expected to put in a little extra work to earn the work study hours". The institutional contexts in which these cooperatives operate provides them, in some ways, privileges in their operational functions.

Students volunteer their time to a cooperative that operates as a student organization or student business, but the co-ops are usually not responsible for paying rent, utility bills, or payroll. The absence of these financial burdens allows them to focus their time and energy on the development, success, and sustainability of the cooperative; sometimes a luxury not afforded to cooperatives who operate outside of a university context. SFCs also typically have large pools of students who volunteer their time with the cooperative for certain tasks, events, or meetings. Some SFCs have upwards of 80 people in their general volunteer pool, as one student mentioned, "in a typical season, we have 75-85 student members who volunteer regularly". Another student mentioned that because of their relationship with the university as a student organization they qualify their membership as the entire student base, "We have a volunteer pool of about 30 people, including our volunteer board of directors, and we have 5 paid staff people. Because we are a student society, every full-time student is a co-op member, which is about 18,000" (CoFED Survey, 2016). These organizations are also sometimes overseen by university professors in the form of faculty advisors or direct liaisons between the students and university administration, 
"We work very closely with the Office of Sustainability. The director of the office handles our accounts with [the university] and is strong advocate for us" (CoFED Survey, 2016).

Most SFCs desire to provide an "alternative" to their campus food landscapes, whether that be qualified by ethical or sustainable standards, the general quality, diversity of options, affordability of healthy and fresh foods, or even providing an alternative food space in and of itself, a space where discussions surrounding food systems and inequalities and injustices related to food, economic, or social issues take place.

Physical space for stores or carts came up in almost every student interview during this study. Many of the cooperatives that actually had a physical store on their campuses highlighted their space as important to their operations and successful functioning of their organization. "[We provide] a space to host events and provide a space for artistic expression," said one student about their cooperative. Another informant stated that their cooperative wanted to provide, "a comfortable and safe space on campus to study and hang out in, as well as an educational space for students to learn about fair trade and co-op politics" (CoFED Survey, 2016). These co-ops not only provide an alternative food source for folks on their campuses, but they also aim to present and accommodate comfortable and "safe" spaces for certain students on campus. This however, calls into question who these "safe spaces" are actually meant for, an issue facing many in the cooperative world.

Space plays an important role for these co-ops; whether they have it or not has huge implications for how successful and sustainable they really are, as it would for any other type of food store. However with a university landlord, the questions of space can become contentious when SFCs, who seemingly operate autonomously, also have to answer to their institutions. 
As mentioned previously SFCs form for a number of reasons, usually to meet a specific need identified within their community such as addressing the lack of access to fresh produce or healthy, ready to eat meals on campus. Student are creating stores to address gaps in food services they have identified on their campuses. However, most SFCs mainly address the issue of access on their campuses; whether it be access to affordable bulk foods, sustainably produced foods, or vegan and vegetarian foods. As one student stated, "our university is classified as a food desert, meaning student have limited to no access to fresh, healthy produce. Therefore, we have to end this status by bringing locally grown produce to members of our university community as affordable prices" (CoFED Interview, 2016). Another student mentioned the lack of options for students who have dietary restrictions, "there are very few vegan and vegetarian options on campus besides [our co-op]. More generally, there are few local food choices on and around campus. We are striving to fill this need with affordable breakfast and lunch choices [for vegans and vegetarians],". Other SFCs are more focused on the sustainability side of these food choices, "We see a lack of sustainable and local food options that are actually affordable.

Students have the right to access such options, and should not be priced out of eating locally and healthy within our campus," (CoFED Survey, 2016).

\section{1) How are Student Food Cooperative Organized?}




\begin{tabular}{|c|c|c|c|}
\hline Worker Co-op & Consumer Co-op & Multi-Stakeholder Co-op & Hybrid Co-op \\
\hline $\begin{array}{l}\text { Cooperative } \\
\text { owned and } \\
\text { governed by } \\
\text { worker-members. } \\
\text { Worker-members } \\
\text { oversee day to day } \\
\text { operations and } \\
\text { implement a } \\
\text { democratic } \\
\text { governance } \\
\text { structure. }\end{array}$ & $\begin{array}{l}\text { Cooperative owned by } \\
\text { consumers with } \\
\text { elected board of } \\
\text { directors and hired } \\
\text { workers. Works do not } \\
\text { have autonomous } \\
\text { power to make major } \\
\text { operational decisions } \\
\text { within the cooperative. }\end{array}$ & $\begin{array}{l}\text { Cooperative with a variety } \\
\text { of stakeholders supporting } \\
\text { the organization. This } \\
\text { governance structure } \\
\text { allows for sweat-equity, } \\
\text { worker, and consumer } \\
\text { buy-in members. } \\
\text { Nonprofit stakeholders can } \\
\text { also support these } \\
\text { cooperative initiatives. }\end{array}$ & $\begin{array}{l}\text { Cooperative that } \\
\text { typically brings } \\
\text { together both } \\
\text { worker and } \\
\text { consumer } \\
\text { ownership and } \\
\text { governance } \\
\text { functionalities. }\end{array}$ \\
\hline $\begin{array}{l}\text { EX: Greenleaf } \\
\text { Cooperative Café, } \\
\text { The Maryland } \\
\text { Student Food } \\
\text { Cooperative }\end{array}$ & $\begin{array}{l}\text { EX: UCLA Student } \\
\text { Food Cooperative }\end{array}$ & $\begin{array}{l}\text { EX: Rad Dish Co-op Café, } \\
\text { Berkeley Student Food } \\
\text { Collective }\end{array}$ & $\begin{array}{l}\text { EX: Real Food } \\
\text { Cooperative, } \\
\text { Mixed Nuts Co-op } \\
\text { Cafe }\end{array}$ \\
\hline
\end{tabular}

Like any cooperative, food or otherwise, SFCs are organized in a number of ways, have their own unique committees, and have governing structures that reflect the needs of their organization. Most cooperatives that participated in the study were organized as multistakeholder 
or hybrid cooperatives, meaning that their membership and ownership base are a mixed; not all members are workers, and equity (buy-in) and sweat equity (work-in) are worked into the organizational and functioning structure of the co-op. As one student described their cooperative, "We consider ourselves a multi-stakeholder co-op. We have consumer equity members who pay $\$ 25$ for a voting right and discount at the cafe. We have cafe worker members who are paid for their labor. We also have sweat equity members who exchange volunteer hours for membership benefits. Our committees, all headed by elected students are Academics, Finance, Governance, HR, Solidarity, and Marketing. These heads make up our Board of Directors along with representatives for our Worker members, Sweat Equity members, Equity members and re from the Office of Sustainability. Since [our organization] is both a co-op and a cafe, both parts run a little differently. The cafe is a business co-op model, meaning it's still democratically run. The co-op part is a few steps above from a student organization, allowing us more control over how we run the co-op, what we choose to support, and an individual's membership status" (CoFED Survey, 2016). This cooperative's model is similar, but at the same time much different than other SFCs associated with CoFED, highlighting the differences between cooperatively run food businesses. There is no right way to organize an SFC on a campus. An understanding of how and why the cooperative is forming is needed for the co-op to serve their own mission and goals, as well as their consumers and broader community.

Looking to another example of student run food cooperatives, a worker managed model, a student cooperator described their co-op to be student worker owned. "We have no leaders, and we make all decisions through consensus. We each have equal voting power, and people facilitating discussions change each week. We are all students who volunteer at least two hours a week working the store space, and then generally additional time working on committees. People 
who are not part of the co-op can come to any meetings, but can't vote unless they are a member (which just means they volunteer two hours a week)," (CoFED Survey, 2016). This example highlights a more exclusive, worker-owned and managed cooperative model. Only working members have access to voting, co-op operations and functioning, and proposing projects and goals for the co-op to meet. However, membership is open to anyone with the desire and time to dedicate two hours a week to the organization.

Because time is always an important aspect of volunteering for these SFCs, many of these organizations offer consumer buy in, to expand inclusion of membership but also to provide membership capital for their own organization, a move that can be of great advantage for cooperatives of all types. No cooperative that I have encountered specifically identified themselves a strictly consumer cooperative, meaning fees are a required part of membership, participation, and usually co-op discounts. I speculate that this move is based upon students wanting to maintain their own control over their cooperatives. However, some cooperatives have implemented aspects of consumer ownership into their business models to bolster their own membership base, generate new capital, and also to be more inclusive in regard to membership commitments.

\section{2) Barriers and Challenges Facing Student Food Cooperatives within the University Context}

As any other cooperative faces barriers, so do student run co-ops. The typical ins and outs of cooperative food business formation, development, and success apply to SFCs. However, because of their university contexts, they face challenges outside of "cooperative as usual" dynamics. Student food cooperatives navigate an institutional landscape that can, in one aspect, be supportive, and in another, hinder their success and longevity. Throughout my research over the last two and a half years, I have identified five categories of barriers these SFCs face on (and 
off) of their campuses: Formation, Market Entry, Space, Labor / Resource, and Operational / Competitive.

\subsection{1) Barriers to Formation}

The formation of student food cooperatives is highly varied from campus to campus. There is not a singular recipe or way in which these organizations begin to develop and operate. Most campus food cooperatives start off as small student organizations and clubs on campus; many evolved from Real Food Challenge chapters. Like any student organization, recruitment is key as, without students to participate, you have no club. Tabling, flyer-ing, and class talks are some of the tactics student cooperatives have used to recruit their student and faculty bases. According to one informant, their now university sanctioned co-op started as a bulk buying club based in a student's off-campus apartment. The buying club members would organize faculty, staff, and students on campus to pre-pay for bulk goods that would be housed and distributed from a member's apartment. Another student mentioned their co-op starting as a capstone project of 6-10 people who wanted to research food on campus. They have since recruited over 80 equity members and developed their capstone project into a full cafe on campus. Other interview participants have mentioned their cooperative forming from friend groups or student clubs wanting to explore healthier, sustainable, and more inclusionary food option on their campus, leading them to develop cooperative cafes, carts, bulk buying clubs, and small groceries.

I found that the formations of SFCs on college campuses are somewhat connected to the interests and socio-economic student landscapes of these various schools. Not every school has students who desire food alternatives, sustainable options, and campus food systems change, and not every student who wants these alternatives and healthy, sustainable options resides within an 
accommodating institution. Although these aspects of formation do pose a barrier to the development of campus cooperatives, I do not believe it is an un-winnable challenge.

The language of cooperatives may also pose a barrier to the formation of SFCs. Do students on a particular campus know what a cooperative is and what it means to be a part of it? Some may even have tied a certain type of identity to cooperatives, leading them to think they might not belong or fit in. Whether or not these SFCs have adequate cooperative education materials to de-mystify their enterprises also creates a formational barrier for students to organize and develop their co-ops.

The cooperative and its operational structure can also pose a barrier for student engagement. According to many students interviewed in this study their first co-op experiences come from working with their campus SFC, mostly becoming active because of their interests in sustainable and healthy foods. Even the students who had previous experience with cooperatives, such as day-care cooperatives and grocery cooperatives when they were young, rarely come into their positions within the SFC with extensive knowledge of cooperatives, their fundamental principles, and their powerful possibilities for systematic economic, social, and food change. As one student stated, “There are co-ops all around (in Portland, OR) but I never really understood what was going on. The co-op at the school was the first time I was like 'oh, that's what it means!'” (CoFED Interview, 2016). The knowledge barrier puts some students in the awkward position of being actively involved in their cooperative, but not knowing exactly what they are a part of. Some SFCs have educational workshops and meeting for people wanting to learn more about cooperatives, their principles, history and basic functioning structures.

However, this is not the norm for most SFCs, and it is this juncture where CoFED tends to come in to support. They provide co-op basics in a "Co-ops 101" workshop during their Summer 
Institute. As one student mentioned during the 2016 Summer Institute in regard to the "Co-ops 101” workshop and activity, "Being here makes me feel like I'm part of a movement. It means more than I thought it did" (CoFED Summer Institute, 2016).

Sustaining an organization on a college campus can be challenging, specifically due to the four-year transition cycle. Almost every participant in this study noted the four-year institutional transition as being a great barrier to their co-op's success and longevity. Many students expressed this lack of institutional memory, with one student saying, "we kept forgetting who our staff liaison was. It's hard being in a four-year institution. There are people who have done so much work and we don't know who they are" (CoFED Interview, 2016).

The loss of institutional memory in regard to governance, policies, event planning, and agenda setting stems from student transitions within the SFCs themselves. Some student food coops have sought to address this with handbooks and meeting logs, but with new leadership coming every few years the efficacy of these efforts may be undermined. This is, again, just one of the challenges these student food coops face because of their university contexts.

\subsection{2) Barriers to Market Entry}

Once a co-op or cooperatively-minded student group has formed, there is no guarantee they will have access to their university food market. Entry into the university market as a food vendor is challenging, even for small, non-campus based vendors. These student food cooperatives must meet vending qualifications as well as the demand they might see as a university-based food vendor. The dining context of the university is also important. Whether or not a university has public or private dining services may impact the options SFCs have to develop and serve on campus. It is much easier to win a vending contract with a public dining 
service than it is to become an approved vendor of a large dining company such as Sodexo or Aramark.

According to several students included in this study, administrations have used deferred action techniques and posed issues to students applying for certain university resources. Students noted this as a challenge specifically related to their universities' bureaucratic contexts. Statements also revealed that a few students felt that their university administration used the slow and cumbersome bureaucratic processes to deter students from pursuing certain types of activities, resources, and funding; an appearance of opposition from administration. Some students interviewed in this study mentioned suspicions that certain administrators on their campus would purposefully slow down the inquiries and progress of the food cooperatives in order to keep them from organizing on campus. A few students saw this as their administration averting "food risks" on campus while others saw this as their administration being somewhat "combative" in their pursuit of a student owned and operated food organizations on the campus.

\subsection{3) Spatial Barriers}

I have also identified space to be a contentious issue for student food cooperatives.

Control over a designated space directly relates to the development and successfulness of student run food cooperatives in a number of ways. First, the spatial context of the university itself poses a number of barriers that are tied into challenges listed below. Because these SFCs are mostly operating on campus, there are rules they must abide by that off-campus food cooperatives do not face. For example, hours of operation may be restricted solely because of times the university itself is open. Thus, the autonomy of these SFCs is restricted because of their space. Space also comes into question with the placing of the actual co-op itself. Many students have stated their frustrations with the campus spaces they are given to operate by their administrations, saying 
they are too far out of the way to even compete with other dining options on campus. One student described their location as being in an old maintenance building on the very edge of campus.

Another student mentioned the campus security procedures as a barrier to customers; student IDs are required to enter the building and the door that is right in the cafe spaces is always locked, meaning students and cafe employees cannot even enter through a side door. Space for food preparation is yet another spatial barrier SFCs face. Whether or not students have access to safe and appropriate kitchen facilities to prepare foods has come up in student interviews. In some cases, universities have allowed students to utilize the kitchen spaces of cafes or cafeterias on campus. In others, the contracted dining entity has done the same. However, access to these spaces is not guaranteed and can actually inhibit SFC development and growth, especially if food preparation and provisioning are the goals for these students.

\subsection{4) Labor and Resource Barriers}

College students hold a unique position in the world of labor. With irregular class scheduling, students piece together class work, extracurricular activities, and jobs. Typically, undergraduate students have time in their weeks to volunteer for causes they are passionate about, with some students only taking on extracurriculars because they have no job commitments. The altered time commitments of students make college campuses ripe for peer driven initiatives and volunteer opportunities. However, when considering college labor, we must also be aware of class and wealth constraints of students. Whether or not students have the income ability to volunteer plays a large role in who actually gets to participate.

Yet, because of their university contexts, SFCs must navigate a unique landscape when it comes to labor and resource allocation, especially since most co-ops included in this 
study were volunteer run or university subsidized. The type of university influences the labor and resource barriers SFCs face. As an example, The Green Initiative Fund (TGIF) in California provides funds for students at any of the UC schools who wish to start student led sustainability initiatives on their campus. The Berkeley Student Food Collective was awarded $\$ 90,000$ to start their food business in 2010. It is also not uncommon for individual universities to subsidize SFC initiatives. The Rad Dish Cooperative Cafe was awarded $\$ 70,000$ worth of equipment from their university after they gained cafe space on campus. However, resources like TGIF and university subsidies are not afforded to all students who wish to create SFCs. Other people find ways to raise capital or put up their own money to see the cooperative come to realization, such as the case of the Real Food Cooperative whose initial members put up their own money to get the supplies, accreditation, and food they needed to start serving out of a food cart on campus.

The uneven distribution of funding for these SFCs also leads to the issue of labor, and whether or not these co-ops can afford to officially hire anyone to run them. Many SFCs in this study was either majority or entirely volunteer run. The co-ops who have paid positions are usually grant funded or university subsided, mostly through work-study programs or university student association grants. The lack of paid work makes recruitment, retention, and accountability somewhat tricky. Many students expressed their frustrations with having to balance their co-op commitments with their schooling and, in some cases, paying jobs. Holding cooperative members accountable to certain volunteering tasks was also mentioned as a challenge. As one student stated, "How do you get people interested without making it seem like another homework assignment?" (CoFED Interviews, 2016). In addition to the lack of accountability or interest for volunteering, student must learn to manage their business 
(financing, pricing, book keeping, etc.) as well as their staff with little to no training. This is sometimes mediated with the occasional Business Management major who can apply what they are learning in the classroom, but as some students have mentioned, those people are usually not drawn to their co-ops.

\subsection{5) Operational and Competitive Barriers}

Most student food cooperatives operate in a highly competitive environment with other food entities vying for control of campus dining. Whether the university has a public or private dining service such as Sodexo, Aramark, Bon Appetite, or Metz, competition for student dollars remains a reality for SFCs. Because student cooperatives operate within an already established dining environment, they confront challenges when trying to insert themselves into the campus food landscape.

Sourcing, especially for food cooperatives, can be a driving force behind a consumer's choice to shop and buy goods. That being said, sourcing for the SFCs included in this study was cited as being one of their top operational priorities. SFCs are pushing for an alternative to what is offered on campus; usually prioritizing local, organic, and fair trade certified goods. These options are what separate SFCs from their competition on campus. However, always sourcing in this manner can be difficult at times. When growing seasons end local produce options are reduced, leading to inconsistent seasonal offerings which is a particular issue for cafe cooperatives. When local produce and goods aren't an option, organic is usually prioritized. Organic produce and goods are usually more expensive that conventional food items, making grocery produce and cafe offerings more expensive as well, potentially pricing-out customers (usually students on budgets). The high prices of some of these goods may reflect poorly on the 
cooperative, creating an exclusive, classed environment which does not accommodate their general student community.

Almost every student cited catering conflict as a challenge specifically related to their university's contracted dining services. Any catering orders that faculty, staff, or students want to place for any event on campus must go through the contracted dining service, preventing these SFCs from getting large orders that would boost sales and awareness of their organization. To get around this contractual bind, some SFCs have found loopholes to avoid penalty. "Group takeout orders" have been used by a few SFCs to avoid this conflict. They have found that people on campus want their catering services, but are unable to acquire them for full catering.

Almost every campus with a dining service offers some sort of "meal swipe" program. These programs allow students and parents to pre-load money onto a school connected card, giving those students the option to dine at any of the supported "meal swipe" approved locations. Many colleges charge a higher than usual service fee for dining locations to use "swipes", meaning in addition of having a credit card machine, many of these locations also pay a service fee to the university. These higher than average service and processing fees from the university usually deter SFCs from using "meal swipes" and shut them out of the competitive pool for students using these programs, many using it exclusively for their on-campus dining needs.

Food safety concerns from university administrations have also been identified as a challenge by students throughout this research. Food handler cards are required for any students working on campus in a cafe space, and this certification can be incredibly expensive and inaccessible for some working in co-ops that have little to no financial support for their business. Food safety courses are sometimes required of students even if they are not technically 
established in a brick and mortar building on campus. And some students are barred from even providing foods without explicit university permissions and paperwork.

Student run food co-ops must sometimes navigate corporate dining cafe's menus to make sure their menus have none of the same items or meals as these dining cafes. This conflict varies from school to school and dining service to dining service, but most of the cooperatives included in this study cited this as one of the many contractual challenges they face. For example, if a Sodexo cafe was serving an "organic maple pumpkin soup" the student food cooperative wouldn't be allowed to serve anything resembling that dish.

All of these barriers put student food cooperatives in a particularly precarious situation. On top of trying to maintain a successful food business and managing the ins and outs of maintaining a store, these SFCs face challenges specifically due to the setting. With competition from corporate dining services who have the resources, contracts, and staff to maintain their businesses, students face intensified stressors because of neoliberal dining policies implemented by their universities. The institutional contexts of these student food cooperatives pose a number of challenges to operating a successful food business on campus, especially without contracts, designated serving spaces, and fully paid staff. Facing these barriers, many student cooperatives have found it extremely challenging to operate and maintain successful businesses on campus. The stressors stemming from these barriers have led some SFCs to become defunct. However, at the same time these difficulties are being faced, the creativity and passion these students bring to their challenges is truly inspiring. With the support of CoFED and the resilience of these student cooperators, many of these SFCs have become extremely successful even in the face of adversity. 


\section{3) Transformations and Motivations of Students on Their Campuses}

Part of the process of being in the co-op is the sense of self and belonging. After a 2years of research with these student food cooperatives, the question of how these student food cooperatives are transforming their institutional spaces in regard to advancing food sovereignty and democratizing their control over their campus foodscapes may have not been the right way to pose the original research question itself. After much reflection, the question I should have been asking is "Are these student food cooperatives actually transforming their campus spaces rather than how?". The question initially posed in my proposal may have been too presumptuous, assuming these SFCs were primarily concerned with and actively pushing for campus food sovereignty and their democratic control over their own campus food spaces. My findings from this research suggest that although concepts of food sovereignty and democratizing food spaces are found in the narratives of these SFCs, they are not the main focus of their organizing and collective efforts on campuses. Most students included in this study weren't familiar with the terms "food sovereignty" and "alternative economies", but could describe their co-ops within concepts of these terms without outright using the language.

The transformations these SFCs are pushing forth are more targeted toward changing university spaces of food, not necessarily in the name of food sovereignty, transforming and changing students themselves, transforming the type of education received on campus, as well as changing spaces related to food, cooperatives, and their "communities" in general. Moving from these findings, I have identified and described the ways in which these SFCs are transforming aspects of their university spaces, both inside and outside of the scopes of food sovereignty and democratizing their control over their food decisions on campus. 


\subsection{1) Changing the landscape of access on campus.}

Most students in these SFCs are working toward promoting "access" to healthy foods or sustainable foods on campus. As one interviewee explained, "I was really just here for the sustainability aspect, because that's my thing, good nutritious foods, that's my thing" (CoFED interviews, 2016). While promoting food access itself is one of many core components of the food sovereignty movement, most of the SFCs included in this study were found to be promoting access to foods defined in a very narrow and exclusive manner. "We provide a food options that doesn't exist [on campus] beyond us -with organic, gluten free, vegan and vegetarian options" (CoFED interview, 2016).

However, other student food coops operate to meet needs within their campus communities in relation to access, such as one student co-op located in a food desert with little transportation outlets and dining options beyond their campus, "[Our campus] is defined as a food desert, meaning our students have limited to no access to fresh, healthy, produce. Therefore, we aim to end this status by bringing locally grown produce to members of our campus community at affordable prices". These two examples highlight the differences of student food cooperative priorities and the ways in which their individual goals or "needs" define how exactly they are aiming to transform their campus foodscapes. This juxtaposition of cooperative "needs" also shines light on the motivational factors that lead to student participation, as well as the many differences of SFC structures, missions, and values. Again, this shows the many differences and intricacies of student run food cooperatives across the US; not one is the same as any other.

At the same time these differences exist, similarities are almost always found. One of these similarities that became clear through this study has been the intention to create spaces on campus for students to connect, learn, find a sense of kinship amongst their peers, and to feel 
"safe" while in them. "We provide a physical space where a lot of clubs and groups meet, we as a structure provide a space for us, as peers, to get involved with each other and things that are important to us" (CoFED interviews, 2016). One student described her experience in the cooperative as sort of finding her campus "family", telling how she wants to the do the same for others through the co-op itself, "[We are] creating a community because... it's a big school. And it can get lonely. We have over 30,000 students" (CoFED interview, 2016). A place to foster human connection and community in the frenetic and intimidating space of a large university made a huge difference in their college experience.

Another similarity these co-ops show is the desire to provide a space for their peers and community to have an environment on campus that promotes "healthy" and sustainable eating as highlighted by one student who stated, "We want to give people a space to eat healthy, that's really important to us". And as another student mentioned, "A lot of folks on campus life just off campus and go to one grocery store. No local produce, all organic is packaged. Being able to provide just lunch and more food than prepared is a big win for us" (CoFED interviews, 2016).

"I would say we have a growing impact [on campus]. We're a small operation, so not a large impact. We're still at the beginning. So I think we're starting to get people to think about where their food comes from and starting to get people to take an active role in that. But we still stand at the beginning"

- 2016 CoFED Student Co-op Participant Interview

\subsection{2) Individual Transformation by Engaging with Cooperative Spaces}

Student food cooperatives have more than just spatial transformative aspects, they also change and transform the individual students who participate. These SFCs allow their members to get involved with issues they care about, as well as link them to other educational outlets that tie into cooperative organizing, business models, along with food justice and sovereignty. As a 
student interviewee described her own transformation from her experience with an SFC, "I've never been much of a group member worker before, I've always been off doing my own thing and accomplishing my own goals. [The co-op] is the first thing I've ever been involved with a big group of people. It's been really transformative. I've learned a lot on how to work with people and the great aspects of working with people that i wouldn't have come by naturally. I think working in a cooperative environment has lead me to grow as a person. It's changed my perspectives more than anything else. It's something I want to continue to use in professional venues" (CoFED interview, 2016).

Related to transformations of the self in thinking about food as an entrance into the cooperative food spaces an interviewee noted that prior to coming to their cooperative, he spent five months on an organic farm where he learned the soil and biodynamic sciences of food production. He came from this experience to his university with aspirations to apply it in his higher education work, "I wanted to get involved on campus with initiatives that were less academic and more experiential, certainly something that pulled me to the student collective was that you actually had the opportunity to do real work. I started as a dishwasher with 2 hour shifts of washing other people's dishes, shortly after, I applied to be a cashier and became a cashier, then moved onto the the Board of Directors" (CoFED, interviews 2016). And as another student described their transformation in regard to food, "I've been pretty conscious of food and what food signifies, but being at my co-op has shown me the different ways and how much food is transported through restaurants, and how much waste is produced. We have a close to zero waste operation and getting to see that and be involved is that shows the flip side, not everything has to be waste".

"Before I didn't think about [food], maybe at all. So just getting me to 
think about where food comes from is different"

- 2016 CoFED Student Co-op Participant Interview

\subsection{3) Creating a sense of community and solidarity with one another}

A powerful aspect of these SFCs is the sense of community they create. My findings suggest the sense of community these SFCs provide their student members is related to their own self transformations and their commitments to their co-ops, their peers, and the causes and issues they address within and outside of their cooperative spaces. As one student described her experience with her co-op, "When I got elected as marketing committee head, it was like oh my god, I matter. I'm a part of this group now and they recognize I have something to offer" (CoFED Student Interview, 2016). The sense of community and commitments made the co-op itself create a path for a transformation of self and self-worth. These spaces provide experiences for students to "belong" and find their interests within the context of food and cooperation.

\section{8) How is CoFED Navigating Student Cooperative Barriers?}

The way in which student food cooperatives have been cultivated and supported by CoFED has historically placed them in the center of food politics on their campuses, attracting students with particular, very specific interests surrounding food; local, healthy, sustainable, diverse, and fair trade.

Throughout this research, I've found these are buzz words for many students exploring their own interests and passions on college campuses; it seems relatively easy to find people with a surface understanding and interest in "entry level" food justice. Concepts of cooperativism, food sovereignty, and democracy are not necessarily the driving forces behind student 
engagement in student food cooperatives, but are an educational end goal for CoFED to achieve through their Summer Institutes.

Over the past three years, the organization has shifted and evolved its programming, curriculum, and outreach efforts to reflect changing sentiments within the social, economic, and cooperative landscapes across the United States. These shifts can be seen as a reflection of changing motivations in the overall mission, vision, values, and goals of CoFED over the last three years, toward more equity engagements within communities, breaking down racial barriers of cooperative spaces, and reflecting more and more on apparent issues within the social landscape of the US as a whole.

The original goal of the Cooperative Food Empowerment Directive was to create a national network of students operating and developing cooperative food businesses in the United States. It has since not only become a network of student cooperators, but an organization that provides tools and trainings to students and young people between the ages of 18-30 to develop and grow their cooperative organizations to be equitable, just, inclusive, and transformative. Now, rather, there seems to be a shift toward creating more diverse collectivities in food cooperatives.

The transition from the CoFED of 2015 to the CoFED of 2017 highlights the importance the organization has placed on a baseline of justice before food alternatives. In the summer of 2015, CoFED launched its first formal Summer Co-op Academy, hosting over 10 student cooperators from across the country, most of whom identified as white. The academy took place in Oakland, California, just outside of Berkeley, the founding city of CoFED. Since 2010, CoFED has organized youth mainly on the west coast, and more recently across the nation, to 
educate and teach students on college campuses about alternative business, sustainable food systems, cooperative economics, and the basics of creating and operating a student run food cooperative. In 2015, I was a part of the Summer Academy Cohort with the main focus of this particular academy being the creations of equity stakes; how to infuse not only equality but equity into these businesses from the start. This equity push, although extremely valuable and needed within student learning of cooperatives, was heavily influenced by the current Executive Director, who came from a background in policy research and implementation, rather than cooperative business or food systems. This cohort's educational trajectory touched on racial justice as an outside stressor for cooperatives, but did not necessarily come to a point where they addressed racial oppression, white supremacy, and discrimination within co-ops themselves outright. This has been a major mission shift since CoFED's summer academy beginnings.

The 2015 Summer Institute was heavily focused on utilizing universities resources and leveraging student power to create and develop cooperatives on campuses. Strategic planning of university assets was a major focus during this week; partnerships with dining services were suggested by staff and guest speakers, bringing into question the true cooperative and autonomous structuring of these student organizations.

The politicization of food was a topic of conversation at the 2015 Summer Institute as well. However, the political aspects of food were only briefly introduced, but not truly discussed detail. CoFED staff began the conversations, but did not go as deep as they could. This Summer Institute was more focused on developing an enterprise rather than specifically promoting food justice and cooperative principles.

With a changed and transitioning staff from the first Summer Institute, the 2016 curriculum also shifted. While equity within co-ops was still stressed, racial aspects of food 
cooperatives, alternative food movements, and food justice were brought into the discussion and were more prominently addressed during this session. Conversations surrounding racial justice were held and reflected upon every day with the cohort, and more difficult conversations surrounding race, white supremacy, and injustices were brought up. There were students in this cohort who had never confronted these terminologies, with one student even asking why these topics were consistently being brought up because he felt they were unimportant to cooperative business development.

With the staff transition over the last three years, new languages were brought to CoFED. The term "food sovereignty" was introduced to CoFED's organizing and educational documents. Definitions of capitalism and neoliberalism were outlined for students in their Institute handbooks. The educational materials were more rooted in systemic issues in which cooperatives have the ability to address and combat. The staff transition from the first Institute to the second allowed for these new concepts to emerge from CoFED's work. Their organizational trajectory shifted to reflect staff interests in addition to current issues within the United States' social and economic landscapes. More speakers of color were invited in the 2016 institute, as well as guests from racial and economic justice movements from around the Bay Area. The conversations at this Summer Institute were more justice rooted, rather than specifically food motivated. Suggestions to collaborate with large dining companies were essentially non-existent during this Institute. With a new program director trained in Critical Political Economies, the idea of working with neoliberal institutions may not have been compatible with their values and work goals.

Over the course of 2016, CoFED's 'about' section on their website shifted its focus.

“CoFED is a training program and national alliance for campus-based food 
cooperatives. The issue of food quality and insecurity on college campuses is serious. The consolidation of our food system, upheld by college institutions, is only perpetuating injustices in our food system, creating ecological and economic crisis that affects us all, and impacting communities of color and low-income communities first and worst." -

\section{CoFED Website (www.cofed.org)}

This demonstrates a major shift in language used by CoFED. In 2016, CoFED also adjusted their mission statement to include food sovereignty, a term not previously used by the organization.

"CoFED partners with college students and administrators to start or scale campus food co-ops with a triple bottom line of food sovereignty, sustainability and social justice. We forefront racial and economic equity at the core of cooperative development" - CoFED Webiste (www.cofed.org).

The third Summer Institute was hosted at the Highlander Center in Tennessee, a center and organization for grassroots organizing and movement building in Appalachia and the United States South. The applicants for the Institute were more scrutinized, with this being the first year CoFED rejected applicants. The staff were actively looking for students coming from Historically Black Colleges (HBCs), community colleges, students and young adults from lowincome backgrounds, and non-college youth. The change in Institute recruitment was a result of the mission shift within the organization. Even more so than in 2016, 2017's Institute was focused on collective liberation, white supremacy within cooperatives and alternative food movements, and food justice work. Over the last three years, CoFED has attempted to "radicalise" its mission beyond just supporting student food cooperatives for the sake of "healthy, humane, and organic" options on campus. More so than years previous, the focus was to address systemic inequalities through cooperatives themselves, educating students on the power of collectivization around food and showing them local examples. 
The 2017 institute was held in a region of the United States CoFED has historically ignored since its inception, the American South and Appalachia. This - again - highlights a mission shift outside national expansion; a direct and strategic move of location for the Summer Institute was brought about because of staff changes over the last year and a half. 2017 also marked the explicit acceptance of non-student and non-university members, focusing on young people, even those outside of a higher education context.

Over the last three years, it is clear that CoFED has been attempting to navigate a changing social, economic, and racial landscape within the United States and food cooperative world. Both the staff and board of CoFED have changed since its inception, with the organizational reflection having taken place over the last year and half. Once an organization mostly educating and supporting predominantly white, affluent students at more progressive universities and colleges, CoFED has identified this organizing strategy as problematic and reflective of the food cooperative landscape of the United States more broadly. I believe a reckoning within the organization has occurred and the concept of organizing student cooperatives for the sake of cooperatives has now been challenged by current and past staff. The basis for organizing and supporting student food cooperatives has changed and now includes a focus on marginalized communities, even those outside of the campus context, and communities with a defined and underserved need. This shifting of CoFED's organizing and educational goals highlights their growth as well as their new attempt to organize youth from a position rooted in justice, not just food. The organizational adjustment also illustrates CoFED's commitments to supporting more radical food movements, aligning and situating themselves within the spectrum of food justice educators and cultivators, as well as immersing themselves within the languages and actions of food sovereignty movements. 


\section{9) Food Cooperatives for Whom? Exclusion within "Inclusionary" Spaces}

One barrier found during this study was both external and internal to the cooperatives themselves. I have identified a barrier to cooperative inclusion. Exclusionary practices are nothing new to food cooperatives, however, they take different forms when placed within the context of the university. Time is one of the biggest barriers to exclusion for student food cooperative, with students on college campuses tending to have more free time than those who work. With downtime in between classes, and in some cases, no job obligations, students generally have the time to participate in student clubs and organization. However, this generalization does not account for students who must work during their college experience or take heavier class loads to maintain crucial scholarships. Students who may want to participate in student food cooperatives many not in fact have the time. Free time during college is generally afforded to more affluent or middle-class students who many not feel the financial strain of living on their own. Volunteering 5-10 hours of time during the week for a food cooperative is not possible for all students, thus showing just one aspect of the inclusion barrier SFCs pose. Another exclusionary aspect student food co-ops face are prices. Because the type of goods provided by SFCs are usually organic, local, or fair trade, they tend to have an image of being too expensive. The foods SFCs strive to serve on campus may be more expensive to purchase because of how they were grown or the limited quantity the co-op is able to buy, leading them to charge more than their corporate dining competitors. Many students see this as highly exclusionary; they can't even afford the foods their peers are making and serving. The perception of the type of space SFCs hold can also be identified as a barrier to inclusion. As one student noted during an interview, they identified their SFCs as socially "white spaces", meaning the membership of their co-op was predominantly white. With this realization, the whiteness of 
their co-op may be affecting their attempts to "diversify" their memberships, and has the potential to tokenize persons of color who are already involved or may want to become members. The whiteness of cooperative spaces is a critique of the cooperative food movement as a whole, not just student food cooperatives. However, the fact that campus spaces are deemed "whitespaces" may be more apparent for people at that university, confined to their campus grounds for engagement, and not the broader community.

The knowledge of what a cooperative is may also pose an exclusionary barrier for students on campus. Since cooperative courses are rarely, if ever, taught in university curriculums, students coming to a university with a food cooperative may not have any idea what it means to be a member or may have preconceived notions about what engagement in a cooperative looks like. This barrier came up a few times during my interviews with CoFED students. Many had no idea what a cooperative was when they joined their SFC. Others had brief experiences with cooperatives as children, but never really had the opportunity to learn more until their participation as college students. No student interviewed during this research was acutely aware of what a cooperative is, how they function, or their potentially radical abilities to address socio-economic inequalities and food systems. This is where I found CoFED to be a huge influencer. Most people coming to their Summer Institutes were unaware of cooperative basics, such as the seven cooperative principles with most also having never heard a clear definition of what a cooperative is. Understandably, most SFCs are generally concerned with keeping their organization afloat, and are not necessarily concerned with or have the time to extensively educate their members on cooperative basics. SFCs are looking to CoFED for cooperative education support through webinars, Summer Institutes, and workbook materials. The foundational element of student food cooperatives, as I've observed, is being supported 
through CoFED's education, leading to the question of whether or not these organizations actually operate as cooperatives before CoFED intervenes. These barriers to inclusion also highlight the need for CoFED's current organizational shift, showing the exclusionary potentials these student cooperatives bring to the table. CoFED is attempting to intervene by organizing and supporting diverse collectivities of youth.

\section{0) Beyond Food Cooperatives to Diverse Collectivities}

When I began this project, my assumptions were that student food cooperatives faced external challenges from corporate dining interest on their campuses, and that the students engaged in these organizations were seeking to change and gain control over their foodscapes on campus through their cooperative initiatives. The original focus of this research revealed blind spots in my study I had not anticipated. My assumptions lead me to ask a particular set of questions surrounding the push for democratic control and food sovereignty on campuses that may have not been best suited for what I found during the two years of my ethnographic research. However, my search for outward-looking challenges was in vain. Student food cooperatives $d o$, indeed, face formidable challenges from outside entities and even from their own universities. As shown in the results section, the barriers SFCs face because of their institutional contexts are extensive, from corporate dining services controlling contracted food distributions, to universities administrations using the four-year transitional cycle of their students to defer student co-op initiatives, to funding and resource shortfalls, student food cooperatives are in challenging positions of development and success not usually faced by nonuniversity sanctioned food cooperatives.

I argue that I have found both external and internal barriers facing student food cooperatives. My original focus was to identify and outline the external barriers in order to 
produce a detailed guideline for students and CoFED to use when organizing campus-based food cooperatives. But, this process also revealed the internal challenges student food co-ops, and arguably all cooperatives, face when organizing for their particular needs. What I have found throughout this research is the need to infuse established, expanding, and burgeoning SFCs with a baseline of justice and equity, something that students may not be equipped to identify and act upon. The identification of this need was partially based upon CoFED's shifting narrative over the last three years. With a transition of staff and shifts within the socio-economic landscape of the US, CoFED's mission has transformed to include the creation of more diverse, just, and democratically controlled collective organizations. The need to address white supremacy, racism, classism, neoliberalism, and capitalism have been introduced more broadly into the educational framework of the organization. The organization's educational work has changed with their desires to create diverse collectivities, not just food cooperatives for food cooperative's sake. The identification of internal struggles of cooperative organizations shows the desire to change the ways in which people populate cooperative models, and the need to populate them with people who understand and actively combat social, racial, and economic injustices that are just as apparent within the cooperative landscape as they outside of it. The shift in CoFED's programming has stemmed from an internal audit of the organization. They had heavily focused on creating the food cooperative itself, rather than paying much attention to who was actually participating in cooperatives and who the cooperatives were actually serving. The internal struggles identified during this process resulted from asking questions surrounding external challenges facing the cooperatives. Though one of the biggest findings of this study does not directly reflect my original research questions, I do not want to minimize the importance of the external barriers facing student food cooperatives. The challenges facing these SFCs are not 
small, especially factoring their relatively small sizes, their competition with international dining corporations, and the navigation of campus specific rules and guidelines they must adhere to. Reflecting upon the barriers detailed in this thesis, it is truly impressive to see how successful these student food cooperatives have become and the progressive campaigns they are pushing on their campuses. However, the external barriers and struggles facing these SFCs may potentially be mediated by paying attention to how the internal struggles are created themselves. A reflexive look into how a cooperative operates may help students navigate their external and institutional barriers in more meaningful ways.

So how do we get back to a basis of justice in developing these student food cooperatives? The organization of diverse collectivities is one, particularly important, avenue to populate cooperatives on a basis of justice. I argue the need CoFED sees to create diverse collectivities reflects upon the entire international cooperative community, moving outside of the notion of food cooperatives being organized solely based upon organic, local, and "natural". Cooperatives are, in many cases across the United States and the Global North, seen as expensive and exclusionary spaces, catering mostly to white, middle class men and women who seek an alternative to conventional foods and products that most people have no other option but to buy. The focus on "local", "organic", "sustainable", and "ethical" foods can be viewed as highly exclusionary and meant for privileged consumers who have the option and resources to afford them. This skews the original and most important aspect of cooperative formation; what does the community need that the cooperative can provide? Why are cooperatives formed without a need first being identified? Why are cooperatives forming in areas of affluence with an abundance of healthy, local, and organic options available? The concept of the cooperative has almost been coopted by a certain demographic of people to perpetuate a perception of cooperatives as "hip" and 
"progressive" entities, not reflecting upon the radical and rich history of cooperatives from all over the world, especially in communities of color.

\section{1) Conclusion}

After conducting this research, it is clear that the student food cooperative world is riddled with challenges, but also full of creativity, possibility, and passion. The students forming these cooperatives come together to support their organizations for a number of reasons, whether it be their passion for sustainable foods, their desire to see their campus provide healthier options to their peers, or their want to create an alternative cooperative business to educate and provide diverse food options for their campus community. These students are pushing radical conversations forward on their respective campuses, all while navigating barriers within the context of their universities and competitive and highly controlled food environments.

Overcoming external barriers from their universities, corporate dining on campus, and students and faculty on campus has proven to be difficult for many of the cooperatives included in this study. In most cases, with persistence, creative thinking, and some unlikely partnerships with corporate dining entities and universities, the majority of obstacles never pose a detrimental blow to SFCs. However, this does not mean these external issues should be underestimated. The very real obstacles facing SFCs challenge the successfulness of their enterprises, and if overlooked or not taken seriously, could ultimately lead to the decline of a cooperative endeavor.

However, as I have revealed in this study, a blind spot in my original research proposal revealed another set of challenges these enterprises encounter: internal struggles for justice within the food cooperative scene more broadly. Over the last two years, it has become clear that CoFED and, in turn, SFCs have become more focused on addressing the need for a baseline 
narrative of justice within cooperatives themselves and the cooperative movement more broadly. This newly highlighted focus can be seen as CoFED, and their cooperative allies, push beyond food and toward the creation of diverse collectivities to address issues related to food within their communities.

The shift in CoFED's programming demonstrates a change in their mission; there is a need to organize diverse collectivities before developing cooperatives. Populating the cooperative model with strong, diverse collectivities could be the basis for creating more just and truly democratic co-ops, rather than infusing justice principles into an already established and (potentially) flawed cooperative. The internal struggles within cooperatives surrounding the issues of white supremacy, classism, and, exclusion could potentially be mediated by this organizing strategy. The cooperative model may not be inherently flawed, but those who populate the model may bring toxicity which creates the internal turmoil that many co-ops face.

I undertook this study of student food cooperatives to look at the ways in which students navigate their university settings, hoping to detail and disseminate my findings back to students in CoFED's cooperative network. During this study, I identified several barriers these SFCs face specifically because of their institutional contexts, but did not anticipate to uncover internal struggles of both the SFCs and CoFED. Over the course of two and a half years, I have witnessed the evolution of a national nonprofit, its shifting mission, and the reflective processes that led to its inevitable changes. This study and the methods employed gather data have yielded findings that I believe will benefit student food cooperatives, as well as food cooperatives outside of the university setting. In the attempt to organize diverse collectivities before developing cooperative enterprises, I believe we, as cooperators, can truly make other worlds possible. 


\section{Works Referenced}

Amin, A., Cameron, A. and Hudson, R. (2003). The alterity of the social economy. In: Leyshon, A., Less, R. and Williams, C. C. (eds) Alternative economic spaces. London: Sage Publications, pp. $27-54$

Alkon, A., and T. Mares. 2012. Food sovereignty in U.S. food movements: radical visions and neoliberal constraints. Agriculture and Human Values 29:347-359.

Allen, J. 2003. Lost Geographies of Power. Oxford and Maiden, Mass.: Blackwell Publishing Altbach, Philip., Cohen, Robert. 1990. American Student Activism: The Post-Sixties Transformation. The Journal of Higher Education 61(1). 32-49.

Ayres, J., and M. Bosia. 2012. Beyond global summitry: Food sovereignty as localized resistance to globalization. Globalizations 8:47-63.

Ball, Stephen. 2012. Performativity, Commodification and Commitment: An I-Spy Guide to the Neoliberal University. British Journal of Educational Studies 60(1). 12-28.

Bose, Purnima. 2008. From Agitation to Institutionalization: The Student Anti-Sweatshop Movement in the New Millennium. Indiana Journal of Global Legal Studies. 15(1). 2013-240.

Bousquet, M. 2009. Introduction. Occupation of the Faculty of Humanities and Social Sciences in Zagreb. The occupation cookbook for the model of occupation of the Faculty of Humanities and Social Sciences in Zagreb. Centre for Anarchist Studies, Croatia.

Carty, Victoria. 2002. Technology and Counter-hegemonic Movements: The Case of Nike Corporation. Social Movement Studies 1(2). 129-146.

Claeys, P. 2012. The creation of news rights by the food sovereignty movement: The challenge of institutionalizing subversion. Sociology 46:844-860.

CoFED. 2015. Summer Institute Handbook.

Community Economies Collective: 2001: Imagining and enacting non capitalist futures. Socialist Review 28, 93-135.

"Co-Operative Identity, Values \& Principles." ICA, ica.coop/en/whats-co-op/co-operative-identityvaluesprinciples.

Cox, J. 2002. Socking to the Sweatshops: A recent history of sweatshop action at UNC. Boiling Point 3(1):5. 
Cravey, Altha. 2004. Students and the anti-sweatshop movement. Antipode 36(2) 203-208.

D’Anieri, Paul., Ernst, Claire., \& Kier, Elizabeth. 1990. New Social Movements in Historical Perspective. Comparative Politics 22(4). 445-458.

DeWinter, Rebecca. 2001. The Anti-Sweatshop Movement: Constructing Corporate Moral Agency in the Global Apparel Industry. Ethics \& International Affairs 15(2). 99-115.

Diani, Mario. 1992. The Concept of Social Movement. The Sociological Review. 40(1). 1-25

Fiarbairn, M. 2012. Framing transformation: The counter-hegemonic potential of food sovereignty in the U.S. context. Agriculture and Human Values 29: 217-30.

Fickey, Amanda. "'The Focus Has to Be on Helping People Make a Living’: Exploring Diverse Economies and Alternative Economic Spaces."Geography Compass 5.5 (2011): 237-48. Web.

Fridell, Gavin. 2004. The University and the Moral Imperative of Fair Trade Coffee. Journal of Academic Ethics. 141-159.

Gibson-Graham, J.k., and Gerda Roelvink. "Social Innovation for Community Economies: How Action Research Creates 'other Worlds'."The International Handbook on Social Innovation (2013): 453-65. Web.

Gibson-Graham, J.k. "Diverse Economies: Performative Practices for 'other Worlds'" Progress in Human Geography 32.5 (2008): 613-32. Web.

Gibson-Graham, J. K. The End of Capitalism (as We Knew It): A Feminist Critique of Political Economy. Cambridge, MA: Blackwell, 1996. Print.

Glassman, Jim. 2001. From Seattle (and Ubon) to Bangkok: the scales of resistance to corporate globalization. Environment and Planning D: Society and Space 19. 513-533.

Goodman, Michael. 2004. Reading fair trade: political ecological imaginary and moral economy of fair trade foods. Political Geography 23891 - 915.

Guthman, Julie., 2006. Neoliberalism and the making of food politics in California. Geoforum 39(3):1171-1183.

Haroon Akram-Lodhi and C. Kay, eds. Peasants and globalization: political economy, rural transformation and the agrarian question. London: Rouledge, pp. 288-311.

Hebdige, Dick. 1979. Subculture: The Meaning of Style. New York. Routledge.

Holt-Gimenez, E. "Food Security, Food Justice, or Food Sovereignty?” Food First Backgrounder 16, no. $4(2010)$ 
Holt-Gimenez, E. and A. Shattuck. "Food Crises, Food Regimes and Food Movements: Rumblings of Reform or Tides of Transformation?” Journal of Peasant Studies 38, no. 1 (2011): 109-144. Hopkins, Peter., Todd, Liz., \& Newcastle Occupation. 2012. Occupying Newcastle University: Student Resistance to Government Spending Cuts in England. The Geographical Journal 178(2). 104109.

Kurtz, Hilda E. 2015. Scaling food sovereignty: Biopolitics and the struggle for local control of farm food in rural maine. Annals of the Association of American Geographers 105 (4): 859.

Law, J. and Urry, J. 2004: Enacting the social. Economy and Society 33, 390-410.

Lee, R. (2006). The ordinary economy: tangled up in values and geography. Transactions of the Institute of British Geographers 31, pp. 413-432.

Lefebvre, H. (1991). The production of space. Oxford, OX, UK: Blackwell

Marsden, Terry. 2000. Food Matters and the Matter of Food: Towards a New Food Governance?. European Society for Rural Sociology 40(1). 20-29.

McCann, Carole and Kim, Seung-kyung. (2013). "Feminist Theory Reader: Local and Global Perspectives". Routledge.

Milstone, David. (2010). "Outsourcing Services in Higher Education: Consider the campus climate”. The Bulletin. 78 (2). Web.

Naples, Nancy. (1998). Community Activism and Feminist Politics: Organizing across race, class, and gender. New York. Routledge.

National Center for Education Statistics. (2017). "College and University Education: Enrollment".

Nugent, David. "Understanding Capitalism: Historically, Structurally, Spatially." Locating Capitalism in Time and Space: Global Restructurings, Politics, and Identity. Stanford, CA: Stanford UP, 2002. 61-78. Print.

Oberhauser, A. M. (2005). Scaling gender and diverse economies: perspectives from Appalachia and South Africa. Antipode 37 (4), pp. 863-874.

Oberhauser, A. M. (2004). Women's collective economic strategies and transformation in rural South Africa. Gender, Place and Culture 11 (2), pp. 209-228.

Ovetz, Robert. 1996. Turning Resistance into Rebellion: Student Movements and the Entriprenurailization of the Universities. Capital and Class 20(1). 113-152.

Patel, Raj. "Food sovereignty." (2009): 663-706.

Peck, Jamie., Tickell, Adam. 2002. Neoliberalizing Space. Antipode. 380-404. 
Rheingans, Rowan. Hollands, Robert. 2013. 'There is no alternative?': Challenging Dominant Understandings of Youth Politics in Late Modernity Through a Case Study of the 2010 UK Student Occupation Movement. Journal of Youth Studies 16(4). 546-564.

Seoane, Jose., Taddei, Emilio. 2002. From Seattle to Porto Alegre: The Anti-Neoliberal Globalization Movement. Current Sociology 50(1). 99-122.

Silvey, Rachel. 2004. A Wrench in Global Works. Anti-Sweatshop Activism on Campus. Antipode 36(2) 191-197.

Silvey, Rachel. 2002. Sweatshops and the Corporatization of the University. Gender, Place, and Culture 9(2). 201 - 207.

St Martin, K. 2005: Mapping economic diversity in the first world: the case of fisheries. Environment and Planning A 37, 959-979.

USFT., 2011. United Students for Fair Trade Withdraws Support from Fair Trade USA/Transfair - Calls for Reform to Fair Trade Standards. www.fairworldprject.org.

Van Dyke, Nella. 2003. Crossing Movement Boundaries: Factors that Facilitate Coalition Protest by American College Students, 2930-1990. Social Problems 50(2). 226-250.

Warner, Adam. 2005. A Brief History of the Anti-Globalization Movement. University of Miami Law School Institutional Repository 12(2). 237-268.

Wilson, Bradley. 2010. An Alternative to Protest as Usual: Activist Engagement with Fair Trade as a Market and Movement. Between Market and Movement: The Fair Trade Coffee "Buycott" in the United States and Nicaragua. Dissertation: RU. 65-133.

Wilson, Bradley., Curnow, Joe. 2012. Solidarity тм. Student Activism, Affective Labor, and the Fair Trade Campaign in the United States. Antipode 45(3). 565-583.

Windfuhr, Michael, and Jennie Jonsén. "Food Sovereignty." Towards democracy in localized food systems. ITDG Edition, Rugby (2005).

Wittman, Hannah, Annette Desmarais, and Nettie Wiebe. "The origins and potential of food sovereignty." Food Sovereignty: Reconnecting food, nature and community (2010): 1-14.

Wright, S. (2010). Cultivating beyond-capitalist economies. Economic Geography 86 (3), pp. 297-318. 


\section{Appendix A: Interview}

Personal

1. How long have you been at [university name]

2. How did you get involved with your campus cooperative?

4. What is your role in the co-op?

5. What does your co-op $d o$ ?

6. What do you do with your co-op?

7. Do you volunteer your time for the cooperative or are you paid?

8. What motivates you to continue working with your co-op?

9. What excites you to be a part of your cooperative?

10. Can you think of a specific time or moment when you were excited to be a part of the your cooperative?

11. What are the challenges of working with your co-op?

12. Where did you first learn about cooperativism?

13. Do you feel like you know a lot about the cooperative movement?

a. Can you explain your knowledge of the cooperative movement?

\section{Co-op Information}

1. Who would be the main point of contact for your co-op?

2. How long has your cooperative been operating?

3. Is student work paid or unpaid at your cooperative?

4. How many students work at your cooperative?

5. CoFED uses three categories to define stages of cooperative development: planning, established, and expanding. How would you describe your co-op? 
a. Would you add any categories of development?

6. Do you know the differences between worker cooperatives, consumer cooperatives, and multi stakeholder cooperatives

a. What cooperative category would you describe you co-op to be in?

b. Please describe any committees your cooperative has

c. Does your cooperative have a board to directors?

d. Who sits on your board?

e. Are you incorporated as a legal entity?

f. Do you have bylaws?

7. What need does your co-op address on campus and in your community?

8. How does your co-op do book keeping?

9. What is your co-op's annual revenue? (If any)

10. Is your cooperative legally incorporated? (LLC, non-profit, cooperative, etc)

11. How does your coop source its goods?

12. What is your co-op's definition of local?

University Relationship / Challenges

1. Is your co-op university sanctioned?

2. Is your co-op located on university property?

3. Does your university have oversight in the co-op?

4. Was university capital invested in your co-op?

5. Are there other cooperatives on campus? (EX: Housing)

6. Is your university administration supportive of your food cooperative?

7. Has your co-op ever experienced hostility from your university? 
Dining Service Relationship / Challenges

1. Does your university have a corporate dining service provider (Sodexo, Aramark, Bon Appetit) or in house ?

2. Does your co-op have any relationship with with a dining service provider on campus?

3. Has your co-op every considered a partnership with your corporate dining service provider?

4. Do you face any difficulties doing your work as a co-op because of your university's corporate dining contract?

\section{Community Relationship / Challenges}

1. Who participates in your coop?

2. What barriers do you see that could limit participation in your coop?

3. Who does your education reach? Can you provide examples of how your coop employs education?

4. What does your cooperative do to create an inclusive cooperative community and environment?

Open Question about Barriers

1. Other than the challenges I've previously mentioned, could you identify any other challenges your cooperative faces?

Food Sovereignty

1. Can you explain your understanding of food sovereignty?

2. Does your coop incorporate principles of food sovereignty into its values? 


\section{Appendix B: Survey}

1. What is the name of your food cooperative?

2. Who is filling out this survey?

3. May information provided by you in this survey be used in future written or oral presentations of this research?

4. Would you prefer to remain anonymous in any written or oral presentations of this research?

5. How long has your co-op been operating? (What year was it established?)

6. What stage of development is your co-op currently in?

1. Idea

2. Scaling up

3. Established

4. Expanding

5. Other:

7. Please provide specifics regarding your development stage

8. How is your cooperative structured?

1. Worker Co-op

2. Consumer Co-op

3. Multi-stakeholder Co-op

4. Hybrid

5. Other:

9. What committees make up your cooperative structure? (if any)

10. If your co-op has a board of directors, who sits on the board?

11. Does your co-op have a mission statement and/or set of core values? 
12. How many students work and / or volunteer at your co-op?

13. What 'need' does your co-op address on campus?

14. Does your university employ anyone to oversee and/ or work with your co-op?

15. Would you describe your university administration as supportive of your food cooperative?

16. Is your co-op located on university property?

17. Was university capital invested in your co-op?

18. What is your annual revenue (if any)?

19. Does your university contract out their dining services? (partnership with any hospitality agencies?) Or are dining services in house?

20. Does your cooperative face any barriers because of your university's dining services contract?

21. Has your co-op faced any challenges from university administration at any time?

22. Where did you learn about coopertivism?

23. Would you be open to a more in-depth phone or skype interview for follow-up questions? 